2-3-2021

\title{
Indoor Rock Climbing: The Nuts and Bolts of Routesetting Copyright Protection Post-Star Athletica
}

Julie Tamerler

Follow this and additional works at: https://digitalcommons.law.villanova.edu/mslj

Part of the Entertainment, Arts, and Sports Law Commons, Intellectual Property Law Commons, and the Litigation Commons

\section{Recommended Citation}

Julie Tamerler, Indoor Rock Climbing: The Nuts and Bolts of Routesetting Copyright Protection Post-Star Athletica, 28 Jeffrey S. Moorad Sports L.J. 1 (2021).

Available at: https://digitalcommons.law.villanova.edu/mslj/vol28/iss1/1

This Article is brought to you for free and open access by Villanova University Charles Widger School of Law Digital Repository. It has been accepted for inclusion in Jeffrey S. Moorad Sports Law Journal by an authorized editor of Villanova University Charles Widger School of Law Digital Repository. 


\title{
JEFFREY S. MOORAD SPORTS LAW JOURNAL
}

\begin{tabular}{lll}
\hline \hline VOLUME XXVIII & 2021 & ISSUE 1 \\
\hline \hline
\end{tabular}

\section{Article}

\section{INDOOR ROCK CLIMBING: THE NUTS AND BOLTS OF ROUTESETTING COPYRIGHT PROTECTION POST- STAR ATHLETICA}

\author{
JULIE TAMERLER*
}

\begin{abstract}
"Setting isn't just bolting the climbing holds to walls. Setting routes can be described as a form of art."
\end{abstract}

\section{INTRODUCTION}

Because indoor rock climbing is a relatively new sport, many of its legal issues have not yet been explored. ${ }^{2}$ However, indoor rock climbing's rapid increase in popularity will cause the copyright of indoor rock climbing routes to become relevant to the industry's

* J.D. Graduate, Class of 2020, Villanova University Charles Widger School of Law; B.A. in History, Political Science, and Global Studies, Hofstra University, Class of 2015; 200 RYT. Special thanks to Zack Barber, Owner of The Gravity Vault Radnor, Kevin. A. Tamerler, Routesetting Manager at The Gravity Radnor, for encouraging the pursuit of my "Frankenstein," and Celso Leite for his helpful edits. Additional thanks to Judge Michael J. Koury, Jr. for his patience, both in the past and to come.

1. Tips for Route Setting: How to Build Gym Favourites E Avoid Common Mistakes, KITKA, https://kitkaclimbing.com/blog/tips-for-route-setting-avoid-common-mistakes/ [https://perma.cc/U7RL-MNRW] (last visited May 2, 2020) (explaining techniques for improved route setting).

2. See generally McGarry v. Philly Rock Corp., 134 A.3d 97 (Pa. Super. Ct. 2015) (holding climbing gym not liable for Plaintiff's injury because Plaintiff understood the risks of bouldering and proceeded despite risk); see also Bennett Slavsky, Congress Passes Bill Protecting Climbing Access, The First in US History, Climbing (Feb. 27, 2019), https://www.climbing.com/news/congress-passes-bill-protecting-climbingaccess-the-first-in-us-history/ [https://perma.cc/9ZW5-S93N] (detailing passage of Natural Resources Management Act, signed by President Donald J. Trump, which protects rock climbing on designated wilderness land); see also Texas Adds Rock Climbing Liability Protections for Landowners, Access Fund (June 11, 2019), https:/ / www.accessfund.org/news-and-events/news/texas-adds-rock-climbing-liability-protections-for-landowners [https://perma.cc/QZ6X-XCVW] (discussing signing of bill to add liability protection for landowners who allow rock climbing on their property; adding rock climbing to existing protected activities like hunting, fishing, mountain biking). 
legal landscape. ${ }^{3}$ The growth of modern indoor rock climbing gyms has put a spotlight on routesetting. ${ }^{4}$ Today, it is clear that one of the main ways an indoor rock climbing gym becomes and remains successful is through innovative and sensitive routesetting that provides customers with new and challenging climbing experiences. ${ }^{5}$ Routesetting has become its own art form: the routesetter is the artist, the holds are the paint, the blank slab of wall is the canvas, and the climbing customer is the individual experiencing the routesetter's creation. ${ }^{6}$ Although indoor rock climbing routes are works of sculptural art, there is no legal scholarship exploring the potential copyright protection of these works. ${ }^{7}$ As useful articles, indoor rock climbing routes must survive a separability analysis to achieve protection for their fixed, artistic elements. ${ }^{8}$ Currently, indoor rock climbing routes pass separability analysis under the new standard established by the Supreme Court in Star Athletica, L.L.C. v. Varsity Brands, Inc. , allowing the routes themselves to be eligible for copyright protection. ${ }^{9}$

This Comment presents a framework for analyzing the ability to copyright indoor rock climbing routes in light of recent developments established by Star Athletica and subsequent cases. ${ }^{10}$ Indoor rock climbing routes are eligible for copyright protection as artistic sculptural works. ${ }^{11}$ Section II discusses the history of indoor rock climbing and the development of the modern routesetting profession. ${ }^{12}$ Section III advances the framework that proves that indoor rock climbing routes are copyrightable, first by discussing the issue

3. For further discussion on increase in popularity of indoor rock climbing, see infra notes 71-76, 253-255, 271-278 and accompanying text.

4. For further discussion on the growth and importance of routesetting, see infra notes 48-83 and accompanying text.

5 . For further discussion on the importance of routesetting, see infra notes 65-83 and accompanying text.

6. For further discussion on routesetting as an art form, see infra notes $117-125$ and accompanying text.

7. See supra note 2 (discussing the novelty of legal analysis and rock climbing).

8. For further discussion on separability under copyright law, see infra notes 93-183 and accompanying text.

9. For further discussion on indoor rock climbing routes passing a separability analysis under the Star Athletica standard, see infra notes 176-183 and accompanying text.

10. For further discussion on the framework for copyrighting indoor rock climbing routes, see infra notes 84-252 and accompanying text.

11. For further discussion on the framework for copyrighting indoor rock climbing routes, see infra notes 84-252 and accompanying text.

12. For further discussion of the history of indoor rock climbing and the development of the modern routesetting profession, see infra notes 16-83 and accompanying text. 
of articles and separability, then by examining the new test for separability as set forth in Star Athletica and its progeny. ${ }^{13}$ Section IV discusses the details associated with copyright protection for indoor rock climbing routes, comparing and contrasting literal movement with physical aesthetic similarity. ${ }^{14}$ Finally, Section V concludes by discussing the future of the indoor rock climbing industry, how copyright will co-exist with the development of the sport. ${ }^{15}$

\section{Rock Climbing And The Rise of An Industry}

Rock climbing as a sport began as a subset of Alpinism, with certain high peaks and remote areas requiring ascending sheer vertical or overhung cliffs to reach the top. ${ }^{16}$ Early rock climbers were attracted to the powerful, gymnastic, technical methods required to ascend difficult cliffs; and a subset began to seek out cliffs to climb not for the purpose of reaching an otherwise inaccessible area but for the sheer joy and challenge of ascending a difficult section of rock using only their body. ${ }^{17}$ Rather than running into a cliff en route that had to be climbed to reach the top of the mountain, the new breed of rock climbers hiked miles up mountains to reach a cliff for the purpose of enjoying climbing it, then rappelling down and hiking home. ${ }^{18}$

13. For further discussion on the framework that allows indoor rock climbing routes to achieve copyright protection, see infra notes 84-183 and accompanying text.

14. For further discussion on the details regarding copyright protection for indoor rock climbing routes, see infra notes 184-252 and accompanying text.

15. For further discussion on the future of the indoor rock climbing industry, see infra notes 253-282 and accompanying text.

16. See generally Alpinism 101 - An Introduction, SummiтPost, https://www.summitpost.org/alpinism-101-an-introduction/756518 [https://perma.cc/D9GBSY9W] (last visited May 2, 2020) (discussing how other types of rock climb build upon traditional outdoor ("Trad") climbing).

17. See Kimberley Donoghue, The Mental Art of Trad Climbing, Terrain (Jan. 23, 2017), https://terrain-mag.com/the-mental-art-of-trad-climbing/ [https:// perma.cc/YX66-RCE9] (explaining appeal of "trad" climbing by stating "Traditional climbing allows you to climb virtually anywhere that has a line of corners and cracks to work with. You bring your own "protection" - a series of hexes, nuts and different sizes of spring-loaded camming devices - which you fit into the rock. It's like an adult version of the wooden brainteaser puzzles you played as a child, except with slightly higher stakes.").

18. See Best Climbing Areas in WV (And We're Not Talking Just NRG), West VIRGINIA TOuRISM, https://wvtourism.com/east-coasts-climbing-mecca/ [https:// perma.cc/3X5Q-U5RU] (last visited May 2, 2020) (discussing New River Gorge as tourist destination for "the perfect climbing weekend getaway."); see also Mountain Project, REI, https://www.mountainproject.com/ [https://perma.cc/RE46-TGLA] (last visited May 2, 2020) (providing detailed information regarding various types of rock climbing routes throughout world). 
This history is reflected in the Yosemite Decimal System which divides hiking terrain into five "classes" of terrain and denotes sheer vertical climbing as the fifth class. ${ }^{19}$ As rock climbing on fifth class terrain became more popular, the fifth class was divided into grades of 5.1-5.9, denoting increasing difficulty so that climbers could seek out more challenging routes. ${ }^{20}$ As techniques, training, and equipment have developed, additional grades were added above 5.9.21 A 5.9 route, once considered to be an "expert" grade, is now recognized as the end of "beginner" grades, while the highest grades have been pushed into improper fractions of 5.10 and above. $^{22}$ The consensus within the climbing community is that the hardest route in the world, "Silence", is graded 5.15d and goes nowhere in particular. ${ }^{23}$ First ascended by Adam Ondra, "Silence"

19. See Brad Lane, The Yosemite Decimal System, The Clymb, https:// blog.theclymb.com/out-there/the-yosemite-decimal-system/ [https://perma.cc/ N2EF-NKDZ] (last visited May 2, 2020) (discussing danger and difficulty associated with different grades within Yosemite Decimal System, most common system used to grade roped climbs in America).

20. See Willis Kuelthau, Climbing Grades: The Complete Guide, 99Boulders, https://www.99boulders.com/climbing-grades [https://perma.cc/G6GS-X7LP] (last visited May 2, 2020) ("5.9 was the hardest possible grade. But climbers were still getting stronger, and technology was improving. Whenever a climb seemed harder than 5.9, ascensionists would simply call it ' $5.9+\ldots$. ' Eventually climbers realized that the closed system was impractical, so they flaunted the decimal logic and opened grades at 5.10 and above. From 5.10 upward, grades may be further subdivided with a letter from a to $\mathrm{d}$ : $5.10 \mathrm{a}$ is easier than $5.10 \mathrm{~b}$, and $5.11 \mathrm{~d}$ is harder than 5.11c. . . It is now an open-ended system, with new grades opened at the upper limits.”).

21. See Laura Snider, 10 Things You Didn't Know about Camming Devices, CLIMBING (May 23, 2018), https://www.climbing.com/news/10-things-you-didnt-knowabout-camming-devices/ [https://perma.cc/P5DF-2XFP] (discussing invention of spring-loaded camming devices that are inserted into cracks or pockets on rock surfaces; pulling on rope connected to cams cause individual cams to convert pulling force into pressure on rock, creating friction and preventing climber from falling); see also The History of Carabiners, Grivel (Feb. 20, 2019), https:// grivel.com/blogs/grivel-stories/the-history-of-carabiners [https://perma.cc/L7S5Y7BQ] (discussing development of carabiners, "the indispensable link between rope and piton [a metal spike inserted into climbing surface that acts as anchor]: a big step for climbing and a major evolution in the safety possibilities of the climber.").

22. See Hannah Gartner, The Spring of Trad: Three 5.14 FA's Rank Among the World's Hardest Trad Routes, Climbing (June 18, 2019), https:/ /www.climbing.com/ news / the-spring-of-trad-three-5-14-fas-rank-among-the-worlds-hardest-trad-routes / [https://perma.cc/DH32-SFQ9] (reflecting difficult climbs being graded within improper fractions beyond 5.10).

23. See Hayden Carpenter, Adam Ondra - Silence (9c/5.15d), a.k.a. "Project Hard”, Interview, Rock AND IcE (Sept. 11, 2017), https://rockandice.com/climbing-news/adam-ondra-silence-9c-5-15d-interview/ [https://perma.cc/AT83-4BMA] (discussing Ondra's ascension of most difficult sport climb in world). 
ends in the middle of a cliff because that is as far as it is possible to climb. ${ }^{24}$

\section{A. Types of Climbing}

Initially, all rock climbing was what is now denoted as "trad" ("traditional") climbing; trad climbers ascend a route by relying upon carefully placed protection, as well as their belay partner securing the rope should the climber fall. As climbing became more popular, new disciplines developed; sport, top rope, and bouldering. ${ }^{25}$ Sport climbing is the most similar to trad climbing; rather than each climber placing pieces of protection personally, metal bolts are driven into the rock in advance so that all climbers can use them. ${ }^{26}$ Bolt placement makes climbing a route easier, safer, more accessible without specialized equipment and knowledge, and protects the rock from further damage. ${ }^{27}$

Top rope climbing became popular as more climbers ascended small cliffs where the top was already accessible without climbing the rock; rather than put protection in place, the climbers would simply anchor their rope at the top in advance and then climb up, once again increasing safety and accessibility. ${ }^{28}$ Meanwhile, bouldering developed out of climbers casually climbing small outlying boulders of ten to fifteen feet in height that, with padding placed at the ground, could be safely climbed on and fallen off of without utilizing ropes for safety. ${ }^{29}$ Because these shorter climbs might only consist of three to five moves, boulderers focused more on the gymnastic, high intensity moves that could be achieved in short stretches. ${ }^{30}$ Over time, bouldering and sport climbing have developed into distinct disciplines within climbing, focusing on

24. See id. (noting "Silence" was once known as "Project Hard").

25. See Types of Rock Climbing, Explained, CoOL OF THE WILD, https:// coolofthewild.com/types-of-rock-climbing/ [https://perma.cc/5JSE-QDGR] (last visited May 2, 2020) (comparing different types of rock climbing disciplines).

26. See id. (explaining mechanics of sport climbing).

27. See id. (noting added safety of sport climbing).

28. See id. (explaining top rope climbing became popular as more climbers ascended small cliffs where top of cliff was already accessible without climbing the rock, allowing protection to be placed at top of cliff).

29. See Willis Kuelthau, Beginner's Guide to Bouldering: What It Is Ev How to Get Started, 99 Boulders, https://www.99boulders.com/what-is-bouldering [https:// perma.cc/9KDS-EH9B] (last visited May 2, 2020) (providing overview of bouldering style climbing and noting boulder problems typically stand 10 to 15 feet tall).

30. See JP Whitehead, Climbing Techniques: Master Dynos, Climbing (Nov. 10, 2015), https://www.climbing.com/skills/learn-this-master-dynos-with-tips-fromsean-mccoll/ [https://perma.cc/Q4YB-HZEN] (discussing techniques behind dynamic movements that save energy and aid in completing routes). 
pure athleticism and strength rather than endurance or adventure. $^{31}$ These disciplines, in turn, have moved from the cliff face to the indoor rock gym as indoor climbing has increased in popularity. ${ }^{32}$

\section{B. Development of Indoor Climbing}

As rock climbing increased in popularity and specialization, climbers developed methods for training for their sport in the towns they lived in rather than in the wilderness. ${ }^{33}$ The first indoor climbing wall in the world is believed to have been erected in a corridor at Leeds University in Northern England in the 1960s, built for the purpose of helping students learn movements they would need for outdoor climbing. ${ }^{34}$ The first American climbing gym, Vertical World, opened in 1987 in Seattle. ${ }^{35}$ These early gyms were oriented around "hard core" outdoor climbers who needed a space to train and develop the strength needed to succeed on their next outdoor trip. ${ }^{36}$ Many of the specialized tools common in modern climbing gyms, such as the Campus Board and the MoonBoard, developed out of individual climbers that sought to train to complete specific routes and problems outdoors. ${ }^{37}$

31. See John Burgman, A Guide to the Tokyo 2020 Olympic Climbing Format, Climbing (Jun. 20, 2019), https://www.climbing.com/competition/a-guide-to-theolympic-climbing-format/ [https://perma.cc/K3ZA-UUV7] (discussing scoring of climbing at Tokyo Olympics); see also Cedar Wright, The Wright Stuff: Dirtbagging Is Dead, Climbing (Jul. 30, 2014), https://www.climbing.com/news/the-wright-stuffdirtbagging-is-dead/ [https://perma.cc/MD2U-7RVM] (lamenting death of archetypal "dirtbag" climbers, giving rise to climbers who frequent indoor rock climbing gyms).

32. See Katie Heaney, Why Is Everyone I Know Bouldering All of a Sudden?, THE Cut (Jan. 18, 2019), https://www.thecut.com/2019/01/why-is-everyone-i-knowbouldering-all-of-a-sudden.html [https://perma.cc/YR6S-HEEQ] (discussing increasing popularity of indoor bouldering).

33. See The Complete History of Rock Climbing, The Rockulus, https:// www.therockulus.com/history-of-rock-climbing/ [https://perma.cc/9ZV5-ANNT] (last visited May 2, 2020) ("The first artificial climbing walls were made using concrete and rocks. For example, Schurman Wall in Washington State is a part of a city park specifically built for training mountaineers in the 1930's.").

34. See Mick Ward, How the Leeds Wall Changed Climbing History, UKC Climbing (Jan. 30, 2018), https://www.ukclimbing.com/articles/features/how_the_leeds_ wall_changed_climbing_history-10122 [https://perma.cc/6FLX-CXBW] (discussing history of indoor rock climbing).

35. See Vertical World. . . America's First Climbing Gym Celebrates 30 Years, SGB Media (May 23, 2018), https://sgbonline.com/vertical-world-americas-first-climbing-gym-celebrates-30-years/ [https://perma.cc/8HVF-H8EP] (discussing opening and history of Vertical World, which opened "with little more than rocks glued to painted plywood.").

36. See supra note 33 (discussing the history of rock climbing).

37. See Neil Gresham, Campus-Board Training, Rock ANd Ice (Nov. 7, 2017), https://rockandice.com/rock-climbing-training/campus-board-training/ [https:/ 
Tamerler: Indoor Rock Climbing: The Nuts and Bolts of Routesetting Copyrigh 2021]

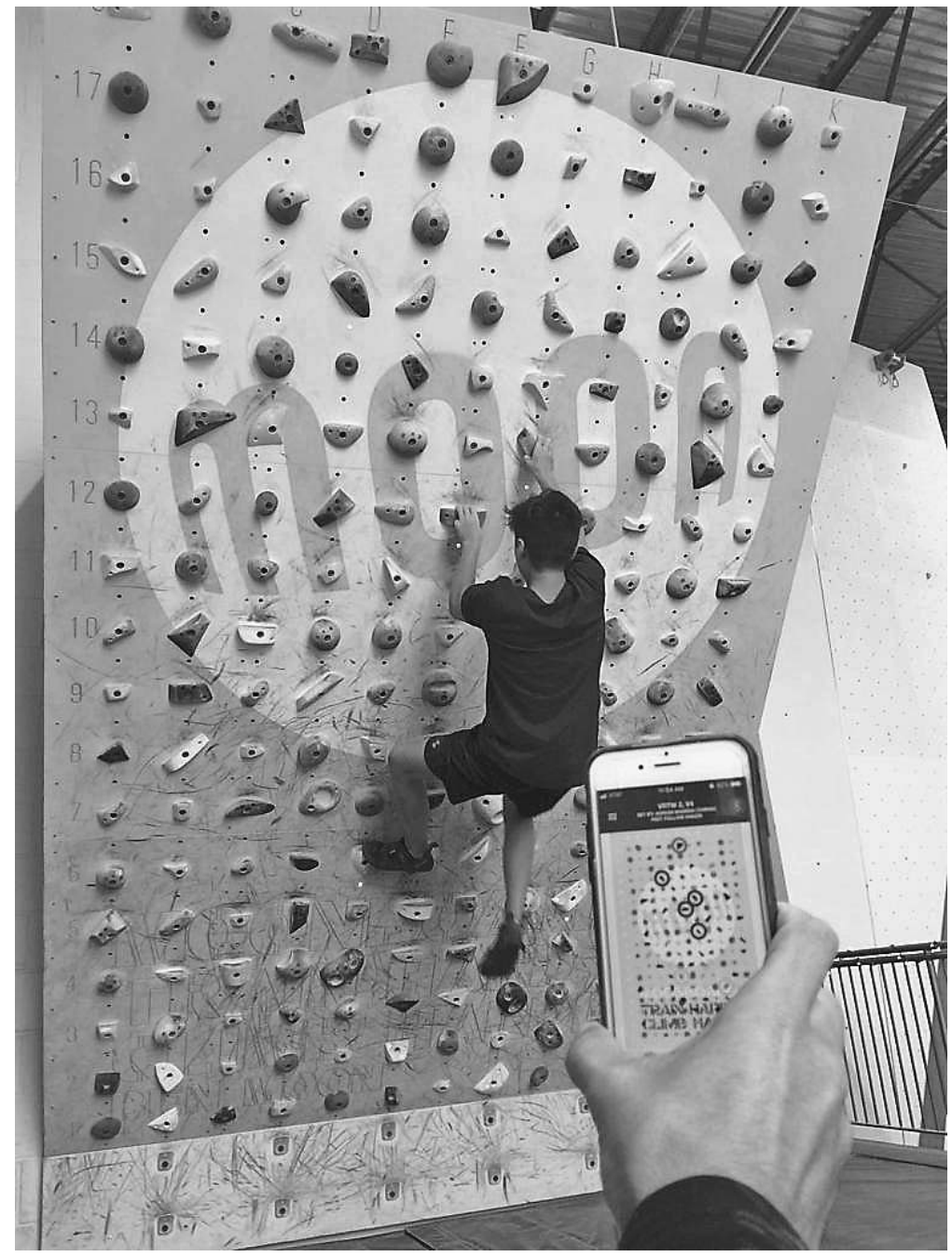

Figure 1: The MoonBoard utilizes LED lights connected to a mobile app, creating problems for the climber to complete. ${ }^{38}$

\footnotetext{
/perma.cc/297Q-JC8E] (explaining how campus board, piece of equipment consisting of series of rungs, is used to develop plyometric finger strength); see also What is the MoonBoard?, MoOnBoARD, https://www.moonboard.com/what-is-themoonboard [https://perma.cc/Q5BD-53KT] (last visited May 3, 2020) (explaining MoonBoard, interactive training wall where user selects climb climbing route via smartphone, which then creates identical setup on Moonboard by utilizing LED light markers beneath pre-installed holds).

38. See Marina Villatoro, Tension Board vs Moon Board [sic] - Indoor Climbing Gym, Travel Experta, https://travelexperta.com/2019/02/tension-board-vsmoon-board-indoor-climbing-gym.html (last visited Oct. 10, 2020) (discussing differences between moon boards and other indoor climbing challenges).
} 
Jeffrey S. Moorad Sports Law Journal, Vol. 28, Iss. 1 [], Art. 1

Jeffrey S. Moorad Sports LaW Journal [Vol. 28: p. 1

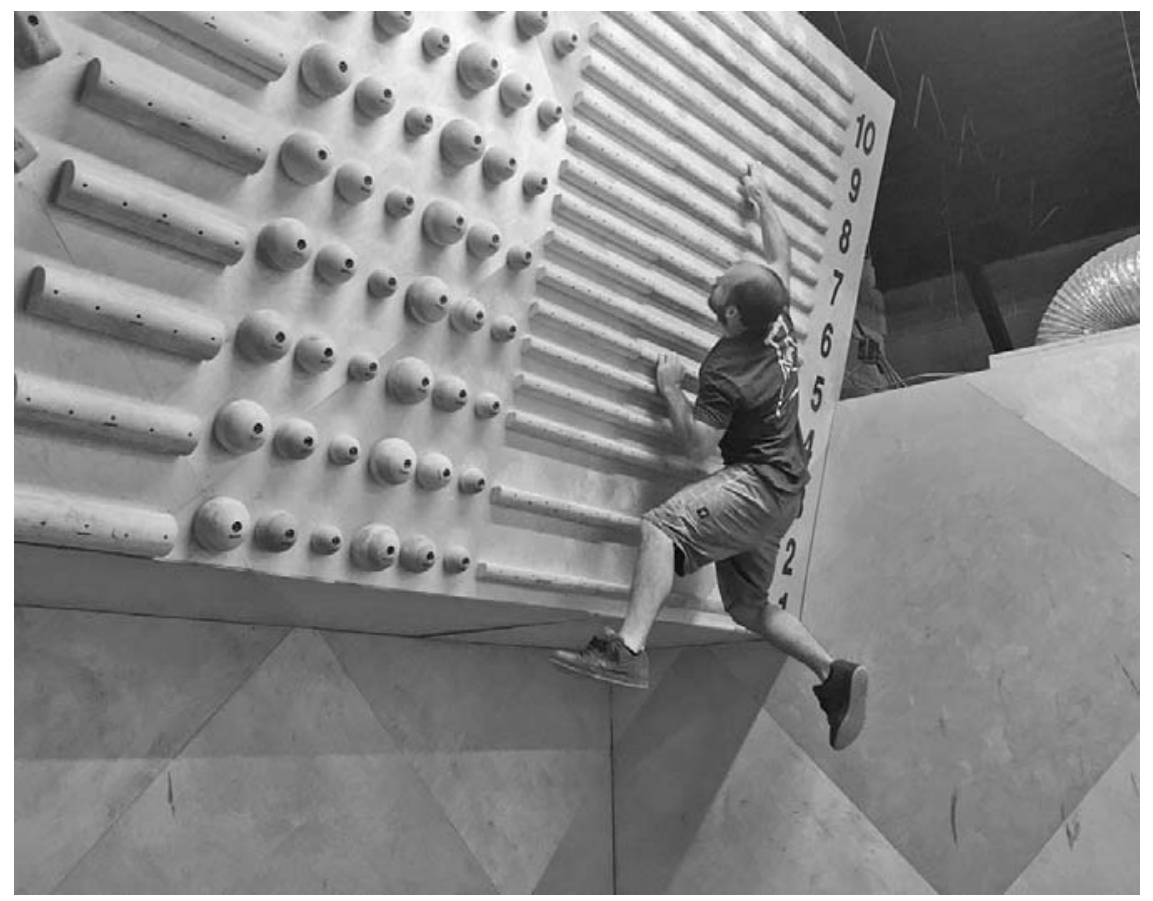

Figure 2: This campus board utilizes rungs that are designed to be climbed without the assistance of a climber's feet. ${ }^{39}$

Over time, locals who had never climbed outside began to view these gyms as fitness facilities or amusements, helping indoor climbing become a unique discipline in its own right. ${ }^{40}$ Indoor climbing's base of customers became spread amongst serious outdoor climbers, hobbyists interested in the sport, and assorted members of the public willing to pay money for a fun activity; as a result, climbing gyms began to set up a variety of different routes on differ-

39. See Introduction to Campus Board Training, FRICTION LABS, https://frictionlabs.com/blog/introduction-to-campus-board-training [https://perma.cc/ E7E4-8CWV] (last visited Oct. 10, 2020) (explaining how to train with a campus board).

40. See Gregory Thomas, Will Rock Climbing Lose Its Soul to Gym Rats?, Outside ONLINE (Mar. 24, 2016), https://www.outsideonline.com/2063681/will-rockclimbing-lose-its-soul-gym-rats [https://perma.cc/JB55-JFJ2] (explaining“"f] or decades, the sport was more religion than athletic endeavor; experience was hard won, gleaned in the crucible of granite. Today, you're more likely to find that kind of devotion channeled into human-created "problems" and color-coded rope routes at your local gym. The advantages of these fitness centers are clear: molded holds and fingerboards build grip strength quickly, and you can crank year-round, with only a few pieces of basic gear. The learning curve has fallen, and the new generation is poised to rapidly push the sport forward."). 
ent terrain to cater to different clientele. ${ }^{41}$ Climbing gyms popped up in cities across the United States, with growth accelerating as indoor climbing became more popular as a form of exercise and as a sport. ${ }^{42}$ Climbing Business Journal's 2019 Gyms and Trends report lists over 600 climbing gyms in the United States, with a net increase of thirty four new gyms in 2019 alone. ${ }^{43}$ The Gravity Vault, an East Coast based climbing franchise, estimates the cost of opening a new franchise location between $\$ 1,085,600$ and $\$ 2,553,462$, not taking into account ongoing franchise fees. ${ }^{44}$ Route Setter Magazine projects 2019 revenue for the industry in the USA and Canada at $\$ 820,000,000 .{ }^{45}$ As more gyms have opened and competition has increased, gyms seek to attract and retain members by focusing on improving their climbing experience. ${ }^{46}$

\section{The Rise of Routesetting}

Early climbing walls consisted of concrete walls with deliberate imperfections or rocks stuck to them for handholds; but in the mid$1980 \mathrm{~s}$, the climbing industry supplier, Metolius, revolutionized the industry. ${ }^{47}$ Metolius began to sell resin holds that attached to the

41. See Adam Nawrot, Cragsters: Meet the Gumby, Climbing (Jan. 31, 2019), https://www.climbing.com/people/cragsters-meet-the-gumby/ [https:// perma.cc/P487-ZGR8] (explaining "gumbies," derogatory slang term for less experienced climbers).

42. See Kate Dwyer, Social Climbing Has a Whole New Meaning, The New York Times (Nov. 14, 2019), https://www.nytimes.com/2019/11/14/style/bouldering.html [https://perma.cc/SS6R-NJXB] (discussing how "climbing gyms are mushrooming like cycling studios before them ... [leading to] a climbing gym in nearly every major city.").

43. See Gyms and Trends 2019, Climbing Business Journal (Feb. 9, 2020), https://www.climbingbusinessjournal.com/climbing-gyms-and-trends-2019/ [https://perma.cc/LE82-APK8] (discussing general growth of indoor rock climbing industry).

44. See Franchising, The Gravity VAult, https://www.gravityvault.com/ franchising [https://perma.cc/AD3Q-QUWZ] (last visited May 3, 2020) (discussing cost and requirements of opening Gravity Vault franchised indoor rock climbing gym).

45. See Garnet Moore, More Research, More Data, and Better Routes: CWA 2018 Indoor Climbing Industry Report, Route Setter Magazine, 2019/20 Issue 2, at 90 (discussing demographics of indoor routesetters).

46. See Emily Attwood, Climbing Gyms Proliferate as the Sport Takes Hold, АтнLetic Business (July 2014), https://www.athleticbusiness.com/fitness-training/ climbing-gyms-proliferate-as-the-sport-takes-hold.html [https://perma.cc/DJP5JBKR] (discussing increasing importance of amenities, architecture, and climbing routes to consumers).

47. See Metolius Origins, Metolius, https://www.metoliusclimbing.com/ metolius-origins.html [https://perma.cc/4E2Z-SDBE] (last visited May 3, 2020) (exploring creation of modern indoor rock climbing holds); see also Don't Call It a Comeback, Climbing Business Journal (May 11, 2015), https://www.climbingbusi nessjournal.com/dont-call-it-a-comeback/ [https://perma.cc/E6TN-3YNM] (not- 
wall using a single bolt passing through the hold, attaching to a threaded nut in the wall. ${ }^{48}$ This system allowed gyms to construct walls that contained a grid of bolt holes, each of which could have a hold bolted to it. ${ }^{49}$ Where early concrete walls were difficult or impossible to modify to create new ways of climbing them, these boltand-t-nut set ups allowed for gyms to put up an infinite number of different climbs by rearranging holds. ${ }^{50}$ Where putting up a new route once meant either constructing a whole new wall or marking holds on or off limits, these new movable holds lead to the creation of a new profession within the indoor rock climbing industry: the routesetter. ${ }^{51}$

Routesetters are individuals responsible for selecting holds from a gym's library of holds, arranging them on climbable surface area to produce new climbs for the gym's clientele.52 Gyms and setters aim to provide climbs at a variety of difficulty levels that (1) are fun to climb; (2) are accessible to climbers with a variety of body types at a consistent level of difficulty; (3) teach and train particular skills; (4) look aesthetically pleasing on the wall; and (5) are enjoyable for climbers to climb repeatedly or to work on as a "project." 53 A gym with 2,000 regulars will average 125 routes, and a majority of commercial setters set multiple days every week, setting three to seven routes each day. ${ }^{54}$ Thus, a gym's routes are in constant flux, and there is a need for consistent professional routesetters who can produce climbs that reliably meet the criteria of member enjoyment and aesthetic attractiveness. ${ }^{55}$ While surveys found that a

ing "Those first holds were tiles that could be fit together to create a route. Most setters today would not recognize these tiles as holds, so much as flat volumes with too many options.").

48. See id. (discussing origins of commercial indoor rock climbing holds).

49. See id. (explaining creation of tile style holds).

50. See 9 Routesetting Essentials, Climbing Business Journal (Apr. 20, 2015), https://www.climbingbusinessjournal.com/9-routesetting-essentials / [https:// perma.cc/57XX-PWAB] (discussing methods of affixing indoor rock climbing holds to walls).

51. See Mathieu Elie, Routesetting: History and Philosophy, Bloc SHOP (Nov. 15, 2016), https://blocshop.com/en/1002/ [https://perma.cc/BLV9-XA2Q] (discussing history of routesetting).

52. See id. (exploring role of routesetters in contemporary society).

53. See Michael Tousignant, Low grades, high expectations!, Awesome Route SETTING (Aug. 18, 2017), http://awesomeroutesetting.com/category/tips/ [https:// perma.cc/QAP4-XTT3] (discussing things to keep in mind to improve route setting).

54. For further discussion of average settings and combined routes by membership, see supra note 45, at 67, 91 and accompanying text.

55. See infra note 261 (discussing how the desire for better routesetting has resulted in routesetting becoming more formalized profession). 
small majority $(65 \%)$ of routesetters set for only one gym, 35\% set for an average of two or three gyms. ${ }^{56}$

\section{The Modern Routesetting Profession}

In many gyms, setting began as an amateur activity, engaged in primarily on a volunteer basis by stronger climbers interested more in community plaudits than in monetary reward; this is still the norm in smaller climbing gyms. ${ }^{57}$ However, as the indoor climbing industry has become increasingly commercialized and profitable, good routesetters are professionalized and compensated accordingly. ${ }^{58}$ Gyms invest heavily in equipment and personnel in an effort to maximize their ability to provide good routes. ${ }^{59}$ On average, gyms spend $\$ 7,000-14,000$ on new holds every year. ${ }^{60}$ Training programs offered by USA Climbing (USAC) and the Climbing Wall Association (CWA) teach routesetters best practices and techniques. ${ }^{61}$ USAC standards require setters for sanctioned competitions to have undergone certain levels of training to lead setting for higher levels of competition. ${ }^{62}$ Routesetters that possess these qualifications are sought after by commercial gyms holding these competitions, with top pros often traveling hundreds of miles to help set regional com-

56. See supra note 45 , at 67 (discussing statistics regarding routesetters).

57. See infra note 261 (discussing the development of the routesetting profession).

58. See Brendan Borrell, How the World's Most Difficult Bouldering Problems Get Made, Outside Online (Sept. 23, 2015), https://www.outsideonline.com/ 2017711/path-beta-flash-resistance-route-setters [https://perma.cc/8Y8A-QX3P] (discussing the careers of various setters).

59. See Tino Flumara, Construction Costs are on the Rise, Climbing Business Journal (Sept. 14, 2015), https://www.climbingbusinessjournal.com/construction-costs-are-on-the-rise/ [https://perma.cc/J6EB-SWZC] (noting expenses associated with building indoor walls); see also Joe Purtell, Climbing gyms used to only offer dead-end jobs. Now, they're a foothold for a route through the industry., The Colorado Sun (Dec. 5, 2019), https://coloradosun.com/2019/12/05/route-setting-jobs-colorado-climbing-gyms/ [https://perma.cc/X7QT-CJXW] (discussing how gym owners are "willing to invest in the one product [they] sell . . . well-set routes.")

60. See supra note 45 at 67 (discussing how "[a] round $50 \%$ of gyms order new holds every three to six months at an average cost of 3,470 euros (approx. 3,875 dollars).”).

61. See Certification, USA Climbing, http://www.usaclimbing.org/Officials/ Routesetters/Certification.htm [https://perma.cc/MN7C-WZVM] (last visited May 10, 2020) (detailing different levels of routesetter certification); see also Routesetter Education Roundup, Climbing Business Journal (June 16, 2019), https:/ /www.climbingbusinessjournal.com/routesetter-education-roundup/ [https:// perma.cc/N9RL-7JVN] (listing various routesetting clinics).

62. See Certification, Routesetting Committee of USA Climbing (USAC), https://www.usacsetting.net/certification/ [https://perma.cc/T3D5-ZXPA] (last visited May 10, 2020) (detailing what different certification levels allow what levels of competition setting). 
petitions across the country. ${ }^{63}$ Competition to provide the holds and perform the routesetting for the 2020 Tokyo Olympics, the first to feature rock climbing as a sport, was fierce; both companies and routesetters knew that this would be a reputation making turn on the world stage. ${ }^{64}$

\section{E. The Importance of Routesetting}

When indoor climbing gyms first appeared in the United States and Europe, the community of climbers was small and insular, made up primarily of outdoor climbers who saw each other often at local climbing crags and cliffs. ${ }^{65}$ Routes were often set by a mix of staff members and community volunteers, often unpaid or paid in the form of free access to the gym. ${ }^{66}$ Because the setters were close members of the climbing community, their setting typically reflected the average members of the community in terms of the desired routes and styles of setting. ${ }^{67}$ For example, if setters and local climbers are all working on climbing certain difficult outdoor routes in the same areas of the Red River Gorge or Joshua Tree, then the setters will put up routes that are useful to train movements for use in those routes. ${ }^{68}$

63. See Brendan Borrell, How the World's Most Difficult Bouldering Problems Get Made, Outside ONLINE (Sept. 23, 2015), https://www.outsideonline.com/ 2017711/path-beta-flash-resistance-route-setters [https://perma.cc/NM5V-KTP7] (discussing careers of setters).

64. See infra note 201 (discussing routesetting in the upcoming Tokyo Olympics).

65. See Luke Zaleski, Meet the California Crew That Brought Sex, Drugs, and Free Jazz to Rock Climbing - and Made it the Most Stylish Sport of the 1970s, GQ (Sept. 19, 2016), https://www.gq.com/story/stonemasters-rock-climbing-oral-history [https:/ /perma.cc/YLG9-XR45] (exploring "original" rock climbing culture, prior to its massive commercialization).

66. See supra note 59 (noting that "[f] or most of the brief history of climbing gyms, boulder and sport climbing routes have been created by owners, volunteers or short-term employees. Once you got a setting job, there wasn't much room to move up.").

67. See supra note 65 (discussing the history of rock climbing).

68. See Scott Christian, Fitness Goes Vertical: Inside the Crazy Luxurious New Climbing Gyms That Are Redefining the Modern Workout, Men's Journal, https:// www.mensjournal.com/health-fitness/fitness-goes-vertical-inside-crazy-luxuriousnew-climbing-gyms-are-redefining/ [https://perma.cc/G3K2-KDLD] (last visited May 30, 2020) ("When the first indoor rock-climbing gym opened in America in 1987 , it was simply a place for outdoor climbers to keep fit during the winter when they weren't scaling Half Dome during the summers. As the gyms proliferated, they remained little more than dark caves stuffed into industrial warehouses on the outskirts of town where hardcore climbers took the winter edge off."). 
Additionally, there were few rock climbing gyms, and fewer climbers who had access to more than one local gym. ${ }^{69}$ The absence of competition encouraged setters to set primarily for the enjoyment of the setters themselves and their friends, giving gyms little encouragement to invest in routesetting, either in terms of compensation for routesetters or seeking out and managing talented setters. ${ }^{70}$ However, as indoor climbing gyms exploded in popularity and the industry expanded, more climbers had access to multiple climbing gyms within their local area. ${ }^{71}$ As gyms look at how to make their gyms superior to competing facilities, routesetting has become more prioritized and targeted. ${ }^{72}$ Efforts are increasingly being put into improving routesetting quality, including professional development for existing setters and hiring outside setters to add variety to gyms. ${ }^{73}$ Gyms compete not only to put up the best, most artistic, or fun routes overall; they also compete in terms of targeting particular groups of climbers. ${ }^{74}$ "Hardcore" gym climbers desire brutally difficult high grade routes that challenge their States).

69. See id. (discussing previous lack of indoor rock climbing gyms in United

70. See How did you become a route setter - advice needed, UK Cuimbing, https:// www.ukclimbing.com/forums/walls ${ }^{\mathrm{TM}}$ raining/

how_did_you_become_a_route_setter_-_advice_needed-707745 [https:// perma.cc/6FJG-M8DS] (last visited May 30, 2020) (discussing difficulties securing indoor rock climbing routesetting position, highlighting working for free until given paid employment).

71. See Willis Kuelthau, The Statistics Behind the Growth of Rock Climbing E Bouldering, 99Boulders, https://www.99boulders.com/the-growth-of-climbing [https://perma.cc/Y49G-CUHA] (last visited May 29, 2020) (displaying statistical rise in popularity of indoor rock climbing).

72. See Susa Schreiner, How Route Setters Decide on the Success of a Cimbing [sic] Hall, ISPO (Mar. 27, 2019), https://www.ispo.com/en/markets/route-setters-decide-success-climbing-hall [https://perma.cc/HU5F-PX6A] (interviewing chief routesetter Peter Zeidelhack, stating " $[\mathrm{t}]$ he route setting team ultimately determines how successful a climbing [gym] is and whether it will remain so.").

73. See Bonnie de Bruijn, In Search of Female Routesetters, Gripped (Mar. 8, 2019), https://gripped.com/indoor-climbing/in-search-of-female-route-setters/ [https://perma.cc/MVZ9-A223] (explaining how female routesetters contribute to route variety); see also Julie Ellison, Where Are All the Female Routesetters?, REI, https://www.rei.com/blog/climb/where-are-all-the-female-routesetters (last visited May 30, 2020) (advocating for increase in female routesetters because, "[i]n theory, having setters with a diverse range of heights, strengths, styles, and sizes means more accessible problems and routes for climbers of all ability levels and body types.").

74. See Willis Kuelthau, Diversity = Variety: What Does It Mean for Commercial Routesetting?, Climbing Wall Industry (Aug. 28, 2019), https://climbingwallindustry.org/blogpost/1711089/330366/Diversity-Variety-What-Does-It-Mean-forCommercial-Routesetting [https://perma.cc/24R6-5L4P] (explaining routesetter diversity leads to diverse setting, increased customer satisfaction across board). 
strength and allow them to demonstrate technical proficiency. ${ }^{75}$ Beginners want easy routes that are still fun and rewarding to climb. ${ }^{76}$ Shorter climbers want routes that are not restricted by overly long reaches between holds. ${ }^{77}$ Competitive climbers want routes that are set to mimic the routes used in competition, while outdoor climbers prefer routes that help them train for their outdoor projects. ${ }^{78}$ Routesetters have to appeal to multiple groups within the gym, often within the same route. The modern routesetter faces the difficulty of setting a route that is fun and challenging for all types of climbers while also providing a climbing experience that is new and varied. ${ }^{79}$

Routesetters constitute a class of skilled workers creating routes, works of sculptural art, in exchange for money. ${ }^{80}$ There is currently no mechanism to prevent the potential theft of these creations; anyone could walk into a climbing gym, take a photo of a climb, and copy that climb in their own gym, leaving the original setter with no way to protect the fruits of their labor. ${ }^{81}$ Historically, the rock climbing industry has a congenial culture in which gym

75. See Jeff Jackson, Setting the Standard, GymClimber (Jul. 8, 2019), https:// www.gymclimber.com/setting-the-standard/ [https://perma.cc/9NTV-6GWP] (interviewing various World Cup setters, discussing setting style, strategy).

76. See Rock Climbing Grades and Ratings: Growing as a Climber, Kendall Cliffs (Dec. 7, 2016), https://www.kendallcliffs.com/rock-climbing-grades-ratings-growing-climber/ [https://perma.cc/6JYW-FNJ6] (detailing lower grade climbs generally feature good hands, easy footholds, lower levels of incline).

77. See Eric Hörst, Effective Gym Training Strategies (for Route Climbing), Rock AND ICE (Aug. 25, 2015), https://rockandice.com/rock-climbing-training/effective-gym-training-strategies-for-route-climbing/ [https://perma.cc/46PG-LDUJ] (discussing indoor training techniques to improve outdoor climbing performance); see also Michael Tousignant, Fair setting (reach and styles, but mostly reach), AwEsome Route SETting (July 7, 2017), http://awesomeroutesetting.com/fair-settingreach-and-styles-but-mostly-reach/ [https://perma.cc/G8HY-F4K9] (explaining how to set so climbs are not "reachy," referring to climb that is overly difficult for those who are not tall).

78. See Michael Tousignant, 3 lessons from my last lead competition setting experience, Awesome Route Setting (April 15, 2017), http://awesomeroutesetting.com/ category/competition-setting/ [https://perma.cc/T947-RTV3] (discussing goals of competition routesetting).

79. See supra note 53 (discussing how to set in an accessible manner).

80. See John Burgman, High Drama: The Rise, Fall, and Rebirth of American Competition Climbing 311 (Triumph Books 2020) (interviewing Mike Pont, professional routesetter: "I can't really describe what 'just right' means, but I know when I feel it that a route is just the way I want it. And I love that with a wrench and five minutes, I can take that thing apart - it's like pop-up art. It's a thing that I can create, and I take it away; it's there and then it's gone. I love that.").

81. See Jason Stearns, Navigating Intellectual Property Law, Climbing Business JOURNAL (Jul. 25, 2016), https://www.climbingbusinessjournal.com/navigating-intellectual-property-law/ [https://perma.cc/3QWE-JU7T] (applying intellectual property law to indoor rock climbing holds, notably neglecting to advance potential for protection of routes themselves). 
members and employees are regarded as "family members;" however, with increased competition, climbing gyms have to take extra efforts to attract members to their gyms. ${ }^{82}$ Copyright protection for indoor rock climbing routes may help indoor rock climbing gyms protect the setting they paid for and also protect the labor of setters individually. ${ }^{83}$

\section{Indoor Rock Climbing Routes are Copyrightable: A FRAMEWORK}

A valid copyright only extends to copyrightable subject matter, which is defined as an original work of authorship fixed in any tangible medium of expression. ${ }^{84}$ To be original, a work must simply be "original to the author," meaning it is "independently created by [said] author." 85 Independent creation means that the work was created without copying from other works. ${ }^{86}$

Additionally, a work must possess "some minimal degree of creativity" to establish a copyright claim. ${ }^{87}$ According to precedent, "[T] he requisite level of creativity is extremely low. . . [and t] he vast majority of works make the grade quite easily, as they possess some creative spark, 'no matter how crude, humble or obvious it might

82. See John Burgman, Long Live the Absolutely Disgusting, Glorious Indoor Climbing Gym, PATAGONIA, https://www.patagonia.com/stories/long-live-the-dirtbagdungeons/story-18035.html [https://perma.cc/3VQD-ZBUU] (last visited May 17, 2020) (discussing decline of "disgusting" indoor climbing gyms in favor of gyms loaded with amenities in effort to attract customers); see also Katie Civgin, How Rock Climbing Helped Me Find Community and Purpose after College, SELF (Apr. 22, 2018), https://www.self.com/story/how-rock-climbing-helped-me-find-community [https://perma.cc/8A7A-PNSU] (discussing how sense of community emerges within indoor rock climbing gyms); see also Amenities, BroOKLYN Boulders, https:/ /brooklynboulders.com/locations/somerville/ [https://perma.cc/P8HF-PSYB] (last visited Aug. 12, 2020) (listing amenities of Brooklyn Boulders in Somerville, Massachusetts, including group exercise classes, saunas, collaborative workspace).

83. For further discussion of copyright framework for indoor climbing routes and potential benefits of doing so, see infra notes 199-282 and accompanying text.

84. See 17 U.S.C. $\$ 102(a)$ (2020) (establishing fixed tangible medium of expression standard).

85. See Feist Publ'ns, Inc. v. Rural Rel. Serv. Co., 499 U.S. 340, 345 (1991) (holding Petitioner's white pages were ineligible for copyright protection because it was simply factual information listed in alphabetical order; this lacked originality because these facts were not selected, coordinated, or arranged in original manner).

86. See generally Russ Versteeg, Rethinking Originality, 34 WM. \& MARY L. REv. 801 (1993) (proposing new classifications to judge copyright originality, exploring difficulties associated with originality analysis).

87. See Feist, 499 U.S. at 358 ("Originality requires only that the author make the selection or arrangement independently (i.e., without copying that selection or arrangement from another work), and that it display some minimal level of creativity."). 
be." "88 To fulfill the originality requirement, a compilation's materials should be "selected, coordinated, and arranged" with "the principal focus ... on whether the selection, coordination, and arrangement are sufficiently original to merit protection." 89 Although a compilation does not need to be particularly complex to achieve protection, "the more creative the selection, coordination, and/ or arrangement, the more likely it is that the author's compilation will be registered." ${ }^{0}$ It has previously been stated by the U.S. Copyright Office that " $[t]$ he Office may register a work comprised of rocks that are selected, coordinated, arranged, and fixed in such a way as to result in a sculptural work." ${ }^{1}$ Sculptural work, as defined by 17 U.S.C. Section 101, includes "two-dimensional and three-dimensional works of fine, graphic, and applied art . . . diagrams, models, and technical drawings, including architectural plans." 92

\section{A. The Useful Articles Problem and Separability}

Under 17 U.S.C. Section 101, a "useful article" is "an article having an intrinsic utilitarian function that is not merely to portray the appearance of the article or to convey information." 93 Such material is only protected to the extent that is has aesthetic features that can be separated from its utilitarian features; inseparable design features are not protected under copyright law and must seek protection through other methods, like patent law. ${ }^{94}$

88. Id. at 346 (detailing precedent).

89. Id. at 358 (explaining originality requirement).

90. See U.S. Copyright Office, Compendium of U.S. Copyright Office Practices $\$ 312.2$ (2017), available at https://www.copyright.gov/comp3/chap300/ ch300-copyrightable-authorship.pdf [https://perma.cc/K875-BYLX] (noting that "the Office generally will not register a compilation containing only two or three elements, because the selection is necessarily de minimis; see H.R. Rep. No. 941476, at 122 (1976), reprinted in U.S.C.C.A.N. at 5737 (stating that a work does not qualify as a collective work "where relatively few separate elements have been brought together,' as in the case of 'a composition consisting of words and music, a work published with illustrations or front matter, or three one-act plays.'").

91. Id at $§ 312.1$ (providing examples of copyrightable subject matter); see also 17 U.S.C.S. § 102(a) (2020) (establishing that subject matter of copyright includes "pictorial, graphic, and sculptural works," among other categories of works).

92. 17 U.S.C.S. \$ 102(a) (2020) (defining sculptural work).

93. Id. (defining useful article).

94. See H.R. Rep. No. 94-1476 (1976) (stating that "where only elements of shape in an architectural design are conceptually inseparable from the utilitarian aspects of the structure, copyright protection for the design would not be available"); see generally Sonja Wolf Sahlsten, I'm a Little Treepot: Conceptual Separability and Affording Copyright Protection to Useful Articles, 67 FLA. L. Rev. 941 (2015) (discussing issues regarding separability analysis prior to Star Athletica). 
For decades, the classic example of utility mixed with art was Mazer $v$. Stein. ${ }^{95}$ In Mazer, the respondent created china statuette figures that served as bases for electric lamps and sought copyright protection for their creation. ${ }^{96}$ The Court set the useful articles doctrine in motion by holding that artistic articles are protected in "form but not their mechanical or utilitarian aspects." 97 While $\mathrm{Ma}$ zer was relatively straightforward, it pointed to problems to come: conceptualizing a sculpture separately from cords and bulbs of a lamp is simple, but the more enmeshed the useful and aesthetic elements are, the more difficult it is to determine just which parts are aesthetic, and which parts are useful articles.

The Copyright Act of 1976 ultimately reflects the holding of Mazer, stating that useful articles are protectable by copyright only to the extent they have artistic elements that are separable from their utilitarian aspects. ${ }^{98}$ If a useful article contains pictorial, graphic, or sculptural features that cannot be physically separated from that article, the U.S. Copyright Office will apply a conceptual separability test:

Conceptual separability means that a feature of the useful article is clearly recognizable as a pictorial, graphic, or sculptural work, notwithstanding the fact that it cannot be physically separated from the article by ordinary means. This artistic feature must be capable of being visualized either on paper or as a free-standing sculpture - as a work of authorship that is independent from the overall shape of the useful article. . . the feature must be imagined separately and independently from the useful article without destroying the basic shape of that article. A pictorial, graphic, or sculptural feature satisfies this requirement only if the artistic feature and the useful article could both exist side by side and be perceived as fully realized, separate works - one an artistic work and the other a useful article. ${ }^{99}$

95. See generally Mazer v. Stein, 347 U.S. 201 (1954) (holding copyright for statuette attached to lamp was valid despite lamp's functional use).

96. See id. at 202 (stating basis for claim).

97. Id. at 218 (citing Stein v. Rosenthal, 103 F. Supp. 227, 231 (S.D. Cal. 1952)) ("Regulation $\$ 202.8$, supra, makes clear that artistic articles are protected in 'form but not their mechanical or utilitarian aspects.'").

98. See 17 U.S.C. $\$ 101$ (2020) (defining sculptural work).

99. H.R. Rep. No. 94-1476, at 55 (1976), https://law.resource.org/pub/us/ works/aba/ibr/H.Rep.94-1476.pdf [https://perma.cc/BC8L-ZAD5] (explaining conceptual separability); see also U.S. Copyright OfFice, Compendium of U.S. CoPYRIght Office Practices $\$ 924.2(B)$ (3d ed. 2014), available at https:// 
Following this act, however, confusion abounded regarding just what test should be used to determine conceptual separability, and ultimately, copyright. ${ }^{100}$ Finally, in 2017, the court established a formal test for separability with Star Athletica, ultimately finding that the Copyright Act protects the pictorial, graphic, or sculptural features of a design of a useful article; even if those features cannot be physically removed from the useful article, protection is granted as long as they are conceptually separable from the utilitarian aspects of the article. ${ }^{101}$

\section{Indoor Rock Climbing Routes Are Useful Articles}

Indoor rock climbing routes ("routes") are useful articles under 17 U.S.C. Section 101 because their intrinsic utilitarian function is as a training tool to force the climber to make certain movements to complete the climb. ${ }^{102}$ This intrinsic utilitarian function is not merely to portray the appearance of the article; the function is not just to portray a route, like if it were simply drawn on a piece

law.resource.org/pub/us/compendium/ch900.html\#p40 [https://perma.cc/ GPL9-GD2G] ("For example, the carving on the back of a chair or an engraving on a vase would be considered conceptually separable, because one could imagine the carving or the engraving as a drawing on a piece of paper that is entirely distinct from the overall shape of the chair and the vase. Even if the carving or the engraving was removed the shape of the chair and the vase would remain unchanged, and both the chair and the vase would still be capable of serving a useful purpose.").

100. See generally Barton R. Keyes, Alive and Well: The (Still) Ongoing Debate Surrounding Conceptual Separability in American Copyright Law, 69 Оніо Sт. L.J. 109 (exploring different court developed methods to determine separability).

101. See 17 U.S.C. $\$ 101$ (2020) (discussing copyrightable features); see generally Star Athletica, L.L.C. v. Varsity Brands, Inc., 137 S. Ct. 1002 (establishing new separability test); see also H.R. Rep. No. 94-1476, at 55 (1976) (providing legislative history regarding separate identity, independent existence; "[o]n the other hand, although the shape of an industrial product may be aesthetically satisfying and valuable, the Committee's intention is not to offer it copyright protection under the bill. Unless the shape of an automobile, airplane, ladies' dress, food processor, television set, or any other industrial product contains some element that, physically or conceptually, can be identified as separable from the utilitarian aspects of that article, the design would not be copyrighted under the bill.").

102. See Gay Toys, Inc. v. Buddy L Corp., 703 F.2d 970, 973 (6th Cir. 1983) (holding that toy airplane is not useful article because, "other than the portrayal of a real airplane, a toy airplane ... has no intrinsic utilitarian function"); see also Gusler v. Fischer, 580 F. Supp. 2d 309, 317 (S.D.N.Y. 2008) ("As the intrinsic purpose of a design drawing is merely to convey information, the drawing itself is not a useful article under the Act"); see also Superior Form Builders v. Dan Chase Taxidermy Supply Co., 851 F. Supp. 222, 224 (E.D. Va. 1994) ("In short, the [taxidermy] forms in question in this case are not useful articles within the meaning of the Copyright Act because they likewise are only useful in their portrayal of the appearance of the animals."). 
of paper, but for it to be used by the climber to ascend the wall using particular movements.

In contrast, the court in Gay Toys held that a toy plane was not a useful article because "other than the portrayal of a real airplane, a toy airplane ... has no intrinsic utilitarian function[,]" ultimately overturning the district court's reasoning that the utility of the toy was in "permit[ting] a child to dream and to let his or her imagination soar." 103 While it would be accurate to say that an indoor rock climbing route may imitate an outdoor climb, just as a toy airplane imitates a real plane, it still retains its utilitarian function as a training tool that is not merely to portray the appearance of the article. ${ }^{104}$

Unlike non-useful articles, useful articles are not eligible for copyright unless it passes a separability analysis, as explained in $\mathrm{Ma}$ zer. ${ }^{105}$ Section 101 explains this analysis, stating that the item in question "shall be considered a pictorial, graphic, or sculptural work only if, and only to the extent that, such design incorporates pictorial, graphic, or sculptural features that can be identified separately from, and are capable of existing independently of, the utilitarian aspects of the article." ${ }^{06}$ Unfortunately, no guidance was provided regarding "identified separately from" or "capable of existing independently from," causing different circuits to establish their own differing standards regarding separability. ${ }^{107}$

\section{Indoor Rock Climbing Routes Were Uncopyrightable Prior to Star Athletica}

The most notable test for separability was established by the second circuit in Brandir International, Inc. v. Cascade Pacific Lumber Co.. ${ }^{108}$ The appellant in Brandir created a sculptural work called

103. See Gay Toys, 522 F. Supp. at 973 ("Indeed, under the district court's reasoning, virtually any 'pictorial, graphic, and sculptural work' would not be copyrightable as a 'useful article.' A painting of Lindbergh's Spirit of St. Louis invites the viewer 'to dream and to let his or her imagination soar,' and would not be copyrightable under the district court's approach. But the statute clearly intends to extend copyright protection to paintings.").

104. See id. (discussing separability).

105. See generally Mazer v. Stein, 74347 U.S. 201, 217 (1954) ("We do hold that the patentability of the statuettes, fitted as lamps or unfitted, does not bar copyright as works of art.").

106. See 17 U.S.C.S. $\$ 101$ (providing definition of pictorial, graphic, or sculptural work).

107. For further discussion of different separability tests established post-Mazer but pre-Star Athletica; see generally Sahlsten, supra note 94 and accompanying text.

108. See generally Brandir Int'l, Inc. v. Cascade Pac. Lumber Co., 834 F.2d 1142 (holding that bicycle rack was not entitled to copyright protection). 
the "Ribbon Rack," which was a bicycle rack made up of looped tubing. ${ }^{109}$ The appellant then adjusted this sculpture to allow it the functional purpose of being a bike rack. ${ }^{110}$ Although the U.S. Copyright office denied a copyright for the "Ribbon Rack," the appellant brought suit for copyright infringement against another company selling a similar bicycle rack. ${ }^{111}$ The court adopted a new standard for separability, stating that "if design elements reflect a merger of aesthetic and functional considerations, the artistic aspects of a work cannot be said to be conceptually separable from the utilitarian elements."112

To establish separability, "the parties will be required to present evidence relating to the design process and the nature of the work, with the trier of fact making the determination whether the aesthetic design elements are significantly influenced by functional considerations." 113 While an artistic work that is put to a functional work still maintains its protected status, Brandir had adjusted their sculpture to function as a bicycle rack. ${ }^{114}$ The court found the aesthetic and utilitarian were intertwined, with the "ultimate design being as much the result of utilitarian pressures as aesthetic choices [;]" and as a result, the bicycle rack was not eligible for copyright protection. ${ }^{115}$

Under this framework, indoor rock climbing routes would not pass a separability analysis and would not be eligible for copyright protection. ${ }^{116}$ As discussed previously, setting involves not just the consideration of the aesthetic, but the functional. ${ }^{117}$ Rarely does a

109. See id. at 1146 (describing structure of bicycle rack).

110. See id. (stating that adjustment was made to original sculptural work so that it would function as bicycle rack).

111. See id. (providing background regarding protection of bicycle rack).

112. Brandir Int'l, Inc., 834 F. 2d at 1145 ("Conversely, where design elements can be identified as reflecting the designer's artistic judgment exercised independently of functional influences, conceptual separability exists.").

113. Id. at 1145-46 (establishing requirements to establish separability).

114. See id. at 1147 (discussing adjustment made to bicycle rack to improve its functionality).

115. Id. at 1147-48 ("the visually pleasing proportions and symmetricality of the rack represent design changes made in response to functional concerns . . . [T] hus [,] there remains no artistic element of the RIBBON Rack that can be identified as separate ... [A] ccordingly, we must affirm on the copyright claim.").

116. For further discussion of the separability test established by Brandir, see supra notes 108-115 and accompanying text.

117. See Victoria Jacobsen, Route setters at Bend Rock Gym design your fun, THE Bulletin (Mar. 19, 2018), https://www.bendbulletin.com/sports/route-setters-atbend-rock-gym-design-your-fun/article_f3f99205-95dc-5420-b458-

677713bf05d6.html [https://perma.cc/GJ5W-9EL5] ("Setters also take into account the function of a route: If they are designing for a competition, they want to separate the good climbers from the great, so there should be points along the 
setter create a climb that only considers the aesthetic, assuming that is even possible. ${ }^{118}$ For example, when selecting a particular hold to use, the setter must consider how it is meant to be held, and how the climber will have to interact with the hold in an effort to complete the climb as imagined by the setter. ${ }^{119}$ Even if a climb were set in such with an emphasis on aesthetics, the function would still be evaluated. ${ }^{120}$ For instance, a setter can put holds in position on the wall in the shape of a wave, strictly for aesthetic considerations, but it will not constitute a route unless it can be climbed, and its "climbability" will have to be evaluated in an effort to ensure that it is useful to the customers of the gym. ${ }^{121}$ Such a situation would directly mimic the facts of Brandir, although the appellant's work was originally purely aesthetic as a piece of sculpture, its modifications to make it functional meant that the ultimate design was a result of utilitarian choices. ${ }^{122}$ As discussed previously, indoor rock climbing routes are unique in terms of assessing copyright protection because of how deeply the aesthetic and utilitarian are inter-

route where some competitors will fall or get stuck. But that is not how you would design a route for a kids' party"). For further discussion of the functionality of routes, see also supra notes 74-79 and infra notes 118-119 and accompanying text.

118. See Michael Tousignant, How to always end up with five star climbs, AwEsome Route Setting (Jul. 15, 2017), http://awesomeroutesetting.com/how-to-always-end-up-with-five-star-climbs / [https://perma.cc/N2PR-DA72] (explaining that routes should be set to consider safety, fairness, originality, comfort, aesthetic, coherence).

119. See Michael Tousignant, The road to unlimited inspiration (part 2: Where to find inspiration), Awesome Route Setting (Jun. 23, 2017), http://awesomeroutesetting.com/the-road-to-unlimited-inspiration-part-2-where-to-findinspiration/ [https://perma.cc/BNH3-AHXS] (exploring what to consider when selecting holds for constructing a route).

120. See id. (discussing routesetting).

121. See Jenna Stadsvold, How to Set Climbing Routes: Pro Tips for Great Routes, TruBlue Climbing (2016), https://trublueclimbing.com/blog/set-climbingroutes-pro-tips-great-routes.html [https://perma.cc/NC3P-5HS3] (explaining how "setters aim to provide a wide array of routes so climbers can always find something to fit their mood or their training needs"); see also Michael Tousignant, My top 5 ways to get inspired, Awesome Route Setting (Feb. 27, 2017), http://awesomeroutesetting.com/my-top-5-ways-to-get-inspired/ [https://perma.cc/93CT-28Q2] (describing method to create route that begins with putting attractive design on wall; going on to state that " $[\mathrm{t}]$ here are days where I feel more like an artist and instead of thinking about moves[,] I just try to make beautiful shapes on the wall and see afterward if there is a cool sequence coming out of it. This method normally requires more work in the tweaking phase because it is not always climbable nor in the desired grade, but usually after moving a little some holds or adding strategic ones it gives something really interesting and unique.").

122. See Brandir Int'l, Inc. v. Cascade Pac. Lumber Co., 834 F. 2d 1145-48 (discussing adjustment of bicycle rack, impact on copyright claim). 
twined. ${ }^{123}$ In Mazer, it was easy to conceptualize the sculpture making up the base of the lamp in question as separate from the lamp it made up. ${ }^{124}$ In contrast, the useful and aesthetic elements of an indoor rock climbing route are intertwined in the holds and their particular arrangement. ${ }^{125}$

Prior to Star Athletica, indoor rock climbing routes more closely mirror Brandir in that the form of an indoor rock climbing route is at least partly dictated by utility and the aesthetic elements are not conceptually separate from its utilitarian elements. ${ }^{126}$ This confusion only becomes more apparent when comparing indoor rock climbing route to Carol Barnhart, Inc. v. Economy Cover Corp. ${ }^{127}$ Clothing mannequins in Carol Barnhart were found to be ineligible for copyright protection because the court found that the utility of the mannequins ultimately dictated their form. ${ }^{128}$ Asking if utility or form come first for routesetters setting an indoor rock climbing route is almost an impossible question because the two feed into each other out of necessity. ${ }^{129}$ While it appeared that the analysis of the copyrightability of indoor rock climbing routes stopped at separability analysis, everything changed when the Supreme Court established a new separability test in Star Athletica v. Varsity Brands. ${ }^{130}$

123. For further discussion of how the "utilitarian" and "aesthetic" are intertwined regarding indoor rock climbing routes, see supra notes 33-40, 74-79, 117-122, infra notes 191-216, and accompanying text.

124. See generally Mazer v. Stein, 347 U.S. 201, 214-16 (1954) (finding that sculptural artistic element of lamp was eligible for copyright protection).

125. For further discussion of how the elements are intertwined, see supra notes 33-40, 74-79, 117-122, infra notes 191-216, and accompanying text.

126. See id. (exploring interplay of utility, aesthetic elements).

127. See Carol Barnhart Inc. v. Econ. Cover Corp., 594 F. Supp. 364, 371 (E.D.N.Y. 1984) (holding that mannequin was not eligible for copyright protection because they were utilitarian objects that contained no separable work of art).

128. See id. at 370 ("To claim that [the mannequins] are purely artistic creations would be disingenuous. They were admittedly created to display clothing, with hollow backs to facilitate draping the garments and initial manufacture geared to mass production ... [ [I] $\mathrm{t}$ is indisputable that the utility of the forms dominates their creation and purpose. They are fundamentally and foremost mannequins sold in a commercial market for utilitarian purpose, and thus are useful articles.").

129. For further discussion of how the "utilitarian" and "aesthetic" in indoor climbing routes are intertwined, see supra notes 33-40, 74-79, 117-122, infra notes 186-211,191-216, and accompanying text.

130. For further discussion of the new test established by Star Athletica, see infra notes 131-153 and accompanying text. 
B. Star Athletica and its New Two-Part Test for Establishing Separability

Varsity Brands, Inc. (Varsity) is a sports equipment company that primarily produces dance team products and services. ${ }^{131}$ As the respondent in Star Athletica, Varsity held more than 200 copyright registrations for two-dimensional designs that were applied to the surface of cheerleading uniforms produced by Varsity. ${ }^{132}$ These designs consisted of different types of lines, chevrons, and other colorful shapes. ${ }^{133}$ Varsity sued Petitioner Star Athletica, LLC (Star Athletica), another producer of cheerleading uniforms, for infringing on five of Varsity's copyrighted designs. ${ }^{134}$ In determining if the graphics affixed to the cheerleading uniforms were copyrightable, the Court held that:

[A] feature incorporated into the design of a useful article is eligible for copyright protection only if the feature (1) can be perceived as a two- or three-dimension work of art separate from the useful article and (2) would qualify as a protectable pictorial, graphic, or sculptural work - either on its own or fixed in some other tangible medium of expression - if it were imagined separately from the useful article into which it is incorporated. ${ }^{135}$

Ultimately, the court determined that the graphics affixed to the cheerleading uniforms were copyrightable; these graphics were able to be imagined as separate from the cheerleading uniforms and, if applied to a canvas, would constitute a protectable graphic in another tangible medium of expression. ${ }^{136}$

The court looked to Mazer in determining if the separately identified feature, here, the designs affixed to the cheerleading uniforms, had the capacity to exist apart from the utilitarian aspects

131. See Varsity Brands LLC, BLOOMBERG, https://www.bloomberg.com/profile/company/RDL:US [https://perma.cc/5GWH-3XFN] (last visited May 18, 2020) (providing background of Varsity Brands LLC); see also Varsity Brands, VARSITY BRANDS, https://www.varsitybrands.com/ [https://perma.cc/YMN8-EPAL] (last visited May 18, 2020) (displaying overview of Varsity Brands).

132. See Star Athletica L.L.C. v. Varsity Brands, Inc., 137 S. Ct. 1002, 1007 (2017) (discussing uniform design copyrights).

133. See id. at 1017 (providing images of uniform designs at issue).

134. See id. at 1007 (stating cause of action).

135. Id.; see generally Samantha Burdick, Star Athletica Tells the Fashion Industry to Knock-It-Off with the Knockoffs, 46 PEPP. L. REv. 367 (analyzing new separability standard's impact upon fashion industry and "knockoffs").

136. See Star Athletica, 137 S. Ct. at 1012 ("Just as two-dimensional fine art corresponds to the shape of the canvas on which it is painted, two-dimensional applied art correlates to the contours of the article on which it is applied.”). 
of the article, the uniform itself. ${ }^{137}$ Mazer held that "the respondents owned a copyright in the statuette even though it was intended for use as a lamp base[,]" establishing that copyright may be extended to "works of art that might also serve a useful purpose[,]" thus establishing the requirement of separability. ${ }^{138}$ While this appears to be a reiteration of existing and established law, Star Athletica is truly novel because of the flexibility it ultimately applies to the previously established separability analysis. ${ }^{139}$

In applying the new two-part test, the court found that "one can identify the decorations as features having pictorial, graphic, or sculptural qualities." 140 The court stated that "[t]he focus of the separability inquiry is on the extracted feature and not on any aspects of the useful article that remain after the imaginary extraction."141 Additionally, the court "reject[ed] the view that a useful article must remain after the artistic feature has been imaginatively separated from the article ..."142 For example, the statue in $M a$ zer, once separated, did not need to be a functioning nor useful article to remain eligible for copyright protection. ${ }^{143}$ In explaining this logic, the court in Star Athletica stated that "[w]ithout the base, the 'lamp' would be just a shade, bulb, and wires. The statute does not require that we imagine a nonartistic replacement for the removed feature to determine whether that feature is capable of an independent existence."144 As a result, an artistic feature, normally eligible for copyright protection existing independently, would not lose said protection "because it was first created as a feature of the design of the design of a useful article, even if it makes that article more useful."145 Prior to this opinion, courts made a distinction between conceptual and physical separability. ${ }^{146}$ However, because

137. See id. at 1011 (providing legal background).

138. Id. (citing Mazer v. Stein, 74 S. Ct. 460, 469 (1954)) (discussing separability standard).

139. For further discussion examining how subsequent cases put Star Athletica into action, see infra notes 159-175 and accompanying text.

140. Star Athletica, 137 S. Ct. at 1012 (finding copyrightable features within uniform design).

141. Id. at 1013 (providing reasoning for new separability standard).

142. Id. at 1014 (establishing "imaginary separability" standard).

143. See generally Mazer, 347 U.S. 201 (providing copyright protection for lamp with decorative statue base).

144. Star Athletica, 137 S. Ct. at 1014 (elaborating upon reasoning for "imaginary separability" standard).

145. Id. (providing avenue for copyright protection of artistic features that may be intertwined with useful articles).

146. See id. ("some courts and commentators have adopted based on the Copyright Act's legislative history. . . . [A]ccording to this view, a feature is physically separable from the underlying useful article if it can 'be physically separated from 
the Court rejects the notion that a useful article must be remain after separating out the artistic feature, Star Athletica abandons the distinction between physical and conceptual separability. ${ }^{147}$

Although the aim of Star Athletica was arguably to simplify the useful articles doctrine and its subsequent separability analysis, some argue that it is more confusing than ever. ${ }^{148}$ In criticizing the majority's opinion, Professor Rebecca Tushnet states:

However, framing the test in the way the Court did isn't any help in identifying articles (or parts of articles) that shouldn't be protected by copyright because of the useful functions performed by their creative aspects. . . . [T] he best way to read the Court's statements about features that contribute to utility should limit copyright's protection to features that are functional only by factual accident-features that just happen to make this particular article a functioning object, rather than features that make the article better at its job than alternative features would, or are cheaper to produce. As Robert Denicola puts it, "[i]f the specific design of the feature is itself important to the arti-

the article by ordinary means while leaving the utilitarian aspects of the article completely intact." ") (citation omitted); see also Chosun Int'l, Inc. v Chrisha Creations, Ltd., 413 F.3d 324, 329 (2d Cir. 2005) (finding that elements of Plaintiff's costumes may be physically or conceptually separable from their overall design, stating that "[i]t might, for example, be the case that the sculpted 'heads' of these designs are physically separable from the overall costume, in that they could be removed from the costume without adversely impacting the wearer's ability to cover his or her body"); see also U.S. Copyright Office, Compendium of U.S. CopyRight OfFice Practices \$924.2(A)-(B) (3d ed. 2014), available at https:// law.resource.org/pub/us/compendium/ch900.html\#p40 (discussing physical and conceptual separability).

147. See Star Athletica, 137 S. Ct. at 1014 ("Because we reject the view that a useful article must remain after the artistic feature has been imaginatively separated from the article, we necessarily abandon the distinction between 'physical' and 'conceptual' separability, which some courts and commentators have adopted based on the Copyright Act's legislative history.").

148. See id. at 1010 (admitting that interpretation of separability is not effort to shape policy); see also id. at 1034 (Breyer, J., dissenting) ("The Constitution grants Congress primary responsibility for assessing comparative costs and benefits and drawing copyright's statutory lines. Courts must respect those lines and not grant copyright protection where Congress has decided not to do so."); see also Emily Smithey, The Borderlands of Copyright: The Useful-Article Doctrine in Light of Star Athletica v. Varsity Brands, 87 UMKC L. REv. 461, 463 (2019) (criticizing Star Athletica, stating that " $[\mathrm{t}]$ he fact that Star Athletica's new test has not solved the separability issue is a separation of powers problem. Courts cannot be expected to mend statutes that inevitably yield confusing, incoherent results."). 
cle's utility, it should not be considered separable from the utilitarian aspects of that article."149

In creating this new two-part test, all established circuit tests were functionally erased..$^{150}$ Adding to the potential confusion, the Court provides no guidance regarding how to apply this new test, and to date, there is no leading guiding precedent on just how this test should be applied. ${ }^{151}$ While the Court utilizes the example of a printed design on a guitar as being easy to separate from the useful article, this example only serves as guidance for a relatively simple application of their new test. ${ }^{152}$ While the Star Athletica test has been effectively applied to two dimensional features as applied to useful articles, the real ambiguity regarding Star Athletica lies with three-dimensional design in which the three-dimensional aesthetic and artistic features are intertwined with the utilitarian features. ${ }^{153}$

149. Rebecca Tushnet, Shoveling a Path After Star Athletica, 66 UCLA L. REv. 1216, 1226 (2019) (citing Robert C. Denicola, Imagining Things: Copyright for Useful Articles After Star Athletica v. Varsity Brands, 79 U. PIтT. L. Rev. 635, 648-49 (2018)) (examining issues with new separability standard).

150. See Doris Estelle Long, The Unimagined Consequences of Star Athletica's 'Imaginative Separability' Test, IPWAтchDog (Dec. 11, 2017), https:// www.ipwatchdog.com/2017/12/11/unimagined-consequences-imaginative-separability/id=90829/ [https://perma.cc/Q9D8-UBYQ] (exploring impact of Star Athletica's new expansive test).

151. See Stephen Grey, Star Athletica and the Future of Design Litigation, NYU L. J. of Intell. Prop. \& Ent. L. Blog (Nov. 2, 2018), https://blog.jipel.law.nyu.edu/ 2018/11/star-athletica-and-the-future-of-design-litigation/ [https://perma.cc/ 2MXX-ZEWT] ("By offering limited analogies regarding what would or would not constitute a separable element under its new test, the Court has invited a wave of new litigation, each case testing the limits of this new, curious standard.”).

152. See Trenton Davis, A Missed Opportunity: The Supreme Court's New Separability Test in Star Athletica, 33 Berkeley Tech. L.J. 1091, 1114 (2018) ("While applications of the test related to two-dimensional and some three-dimensional designs are unlikely to be difficult so long as they have no part in the functionality of the useful article, applications of the test to functional, aesthetically pleasing threedimensional artworks will be much more difficult.").

153. See id. (discussing difficulty of applying new Star Athletica standard); see also Jetmax Ltd. v. Big Lots, Inc., No. 15-cv-9597 (KBF), 2017 U.S. Dist. LEXIS 138041, *15-16 (S.D.N.Y. 2017) (finding that metal "Tear Drop Light Set," ornamental light made up of molded light with wire frame over cover, was subject to copyright. Second prong of Star Athletica was met because decorative cover was easily removable, not intertwined with utility; "[t] he decorative covers are sculptural works that are capable of existing apart from the utilitarian aspect of the light set, i.e. the light bulbs and other components that cause the Tear Drop Light Set to light a room. The primary purpose of the cover is artistic; once the covers are removed, the remainder is a functioning but unadorned light string"); see also Design Ideas, Ltd. v. Meijer, Inc., No. 15-cv-03093, 2017 U.S. Dist. LEXIS 94489, *7-8 (C.D. Ill. June 20, 2017) ("The bird portion of the Sparrow Clips, [which did not influence the utility of the clip itself,] when identified and imagined apart from the useful article-the clothespin-qualifies as a sculptural work on its own."); see also Alexis Kramer, From Costumes to Clothespins, Courts Grapple With Design Rights, BloOMBerg LAw (Aug. 28, 2019), https://news.bloomberglaw.com/ip-law/from- 
A perfect example of this issue arises when revisiting Brandir. ${ }^{154}$ The court in Brandir ruled that the wire bicycle rack was not eligible for copyright protection because its form was "influenced in significant measure by utilitarian concern and thus any aesthetic elements cannot be said to be conceptually separable form the utilitarian elements." 155 However, it is unclear how Star Athletica would apply to the facts of Brandir. When analyzing the first prong of the Star Athletica test, the bicycle rack could be successfully perceived as a work of art separate from the useful article because its design (the wire rack itself) can be identified separately from and can exist independently of its utilitarian aspects (as a bicycle rack). ${ }^{156}$ Additionally, the bicycle rack would appear to fulfill the second prong of Star Athletica because, as suggested by the Court, it could be drawn on a canvas and thus be fixed in another tangible medium of expression. ${ }^{157}$ Unfortunately, while this hypothetical is useful, courts have not applied this test to three-dimensional designs where the aesthetic and artistic are intertwined with the utilitarian. ${ }^{158}$

\section{Star Athletica in Action: Modern Applications}

The best way to understand how the new separability test applies is to examine recent case law, specifically Silvertop Assocs. v. Kangaroo Mfg. and Lanard Toys Ltd. v. Toys " $R$ " US-Delaware, Inc. ${ }^{159}$ In Silvertop, Silvertop Associates, Inc., doing business as "Rasta Imposta," created and obtained copyright for a banana costume they

costumes-to-clothespins-courts-grapple-with-design-rights [https://perma.cc/ GU3L-487P] (discussing recent applications of Star Athletica, stating that "[t]he recent cases demonstrate that plaintiffs seeking protection for the design features of a useful object should be prepared to identify those features . . ...).

154. See generally Brandir Int'l, Inc. v. Cascade Pac. Lumber Co., 834 F. 2d 1142 (2d Cir. 1987) (holding that bicycle rack was ineligible for copyright protection).

155. Id. at 1147-48 (holding that bicycle rack was ineligible for copyright protection).

156. See Silvertop Assocs. v. Kangaroo Mfg., 319 F. Supp. 3d 754, 764 (D.N.J. 2018) (applying first prong of Star Athletica).

157. See Star Athletica, L.L.C. v. Varsity Brands, Inc., 137 S. Ct. 1002, 1012-13 (establishing that separation may be achieved by applying decorative elements on "painter's canvas"). Athletica)

158. See supra note 152 (exploring limitations of Court's reasoning in Star

159. See generally Lanard Toys Ltd. v. Toys "R" US-Delaware, Inc., No. 3:15-cv849-J-34PDB, 2019 U.S. Dist. LEXIS 46911 (M.D. Fla. 2019) (holding that pencil shaped chalk holder was not eligible for copyright protection); see also generally Silvertop Assocs., 319 F. Supp. 3d at 754 (holding that design of banana costume was eligible for copyright protection). 
created. ${ }^{160}$ Meanwhile, Rasta Imposta discovered that Kangaroo Manufacturing ("Kangaroo") was selling a costume that resembled the Rasta Imposta banana costume. ${ }^{161}$ As a result, Silvertop Associates filed suit against Kangaroo, bringing claims for copyright infringement, among others. ${ }^{162}$ The court found that the costume fulfilled the first prong of Star because "[t]he Court can easily identify the features of the Banana Costume having a pictorial, graphic, or sculptural quality." 163 These features included:

a) the overall length of the costume, b) the overall shape of the design in terms of curvature, c) the length of the shape both above and below the torso of the wearer, $d$ ) the shape, size, and jet black color of both ends, e) the location of the head and arm cutouts which dictate how the costume drapes on and protrudes from a wearer (as opposed to the mere existence of the cutout holes), f) the soft, smooth, almost shiny look and feel of the chosen synthetic fabric, g) the parallel lines which mimic the ridges on a banana in three-dimensional form, and $h$ ) the bright shade of a golden yellow and uniform color that appears distinct from the more muted and inconsistent tones of a natural banana. ${ }^{164}$

Just as in Star Athletica, the court in Silvertop determined that the above mentioned features could be separated from the costume itself and applied to a canvas. ${ }^{165}$ The court also found that the banana costume "has unique pictorial, graphic, or sculptural features that did not exist until it was created[,]" and although "the Banana case).

160. See Silvertop Assocs., 319 F. Supp. 3d at 759 (providing background of

161. See id. at 760 (detailing business dealings that led to infringement of copyright).

162. See id. (describing claims, failed attempts at settlement).

163. Id. at 764 (finding that first prong of Star Athletica was met); see also Day to Day Imps., Inc. v. FH Group Int'l, Inc., 2019 U.S. Dist. LEXIS 110081, *15-16 (D.N.J. 2019) (holding two-dimensional car seat cover designs incorporated into seat covers passed both prongs of Star Athletica, making it eligible for copyright protection). But see Inhale, Inc. v. Starbuzz Tobacco, Inc., No. 2:11-cv-03838-ODW (FFM), 2017 U.S. Dist. LEXIS 201498, *6-7 (C.D. Cal. 2017) (holding that hookah water container was not eligible for copyright because Plaintiffs "[sought] protection not for any particular feature of the water container but for the way the features as a whole [were arranged to make up the container.]").

164. Silvertop Assocs., 319 F. Supp. 3d at 764-765 (listing pictorial, graphic, sculptural features of banana costume).

165. See Day to Day Imps., Inc. v. FH Group Int'l, Inc., 2019 U.S. Dist. LEXIS 110081 , *16 (D.N.J. 2019) (applying aesthetic features to figurative canvas); see also Silvertop Assocs., 319 F. Supp. 3d at 765 (providing background of case). 
Costume is unlikely to end up in the Philadelphia Museum of Art ... it represents artistic and stylistic choices [and i] ts unique features reflect an 'imaginative spark." 166 Silvertop is a perfect example of how directly the new Star Athletica test is able to apply to an item in which the functional is wholly integrated with the pictorial, graphic, or sculptural qualities, in stark contrast to previous tests. ${ }^{167}$

The Star Athletica test is further distinguished in Lanard Toys Ltd. v. Toys " $R$ " US-Delaware, Inc. ${ }^{168}$ In Lanard, the plaintiff, Lanard Toys Limited ("Lanard") created a toy chalk holder for children that was in the shape of an oversized number two pencil. ${ }^{169}$ Lanard then registered a copyright for the chalk pencil, as well as a design patent. ${ }^{170}$ The defendant, Ja-Ru, Inc. ("Ja-Ru") created a similar pencil shaped chalk holder. ${ }^{171}$ Defendant Toys R US-Delaware, Inc. subsequently stopped selling the Lanard chalk holder and began selling the Ja-Ru chalk holder. ${ }^{172}$ Lanard bought suit claiming copyright infringement, among other claims. ${ }^{173}$ Lanard reiterates that the new test established in Star Athletica "protect[s] artistic surface features, applied to the utilitarian object . . . ."174 Lanard did not "identify any specific sculptural 'feature' of the overall design that it maintains is separable," and its features were not able to exist independently as a work of art; as a result, the chalk pencil was not protectable under copyright law. ${ }^{175}$

\section{Indoor Rock Climbing Routes Are Separable Under Star Athletica}

If a court held that indoor rock climbing routes were useful articles, they would not pass a separability analysis prior to Star

166. Silvertop Assocs., 319 F. Supp. 3d at 765 (finding that second prong of Star Athletica was met).

167. For further discussion analyzing previous separability tests and applying said tests to indoor rock climbing routes, see supra notes 108-130 and accompanying text; see also Star Athletica L.L.C. v. Varsity Brands, Inc., 137 S. Ct. 1002, 1012 (2017) ("Applying this test to the surface decorations on the cheerleading uniforms is straightforward.").

168. See generally Lanard Toys Ltd. v. Toys "R" US-Delaware, Inc., No. 3:15-cv849-J-34PDB, 2019 U.S. Dist. LEXIS 46911 (M.D. Fla. 2019) (applying Star Athletica separability analysis to pencil shaped chalk holder).

169. See id. at 3 (explaining facts of case).

170. See id. (discussing case background).

171. See id. (introducing Defendant).

172. See Lanard Toys Ltd., 2019 U.S. Dist. LEXIS 46911, at*3 (detailing events that led to cause of action).

173. See id. (stating claims).

174. See id. at 74 (discussing standard established in Star Athletica).

175. See id. at 74-75 (explaining that chalk holder was not eligible for copyright protection because plaintiffs did not meet separability test established by Star Athletica). 
Athletica; the useful and aesthetic are enmeshed, thus making routes ineligible for copyright protection under virtually every preStar Athletica separability test. ${ }^{176}$ However, indoor rock climbing routes would pass the separability analysis established in Star Athletica. ${ }^{177}$ Although it is unclear how a court would apply the Star Athletica test to an indoor rock climbing route, it appears that both prongs would be met. ${ }^{178}$ As discussed throughout this piece, an indoor rock climbing route is a sculptural work of art and its useful article designation is as a training tool. ${ }^{179}$ It can easily be viewed as a work of art separate from its function as a training tool; as discussed previously, indoor rock climbs are set in a way to be aesthetically pleasing, and routesetters take pride in their artistic contributions to a wall. ${ }^{180}$ While the first prong of the Star Athletica test could be met relatively easily, it is the second prong that is more difficult to predict the outcome of. ${ }^{181}$ Indoor rock climbing routes would meet the second prong of Star Athletica because this prong introduces a concept that departs from Section 101's "existing independently" requirement for the incorporated feature, blurring the line between art and industrial design, ultimately expanding copyright. ${ }^{182}$ The arrangement of holds, or more plainly, rocks, on a wall are a sculptural work, as shown in Kevin Barry Fine Art Assocs. v. Ken Gangbar Studio, Inc. ${ }^{183}$

\section{Depth of Protection: Pushing the Boundaries of Art}

In Kevin Barry Fine Art Assocs. v. Ken Gangbar Studio, Inc., the plaintiff brought suit against the defendant for copying his previ-

176. For further discussion summarizing previous separability tests, concluding that indoor rock climbing routes would not pass separability pre-Star Athletica, see supra notes 110-128 and accompanying text.

177. For further discussion supporting the idea that indoor rock climbing routes would be eligible for copyright protection under Star Athletica, see infra notes 178-216 and accompanying text.

178. See id. (analyzing indoor rock climbing routes under Star Athletica).

179. For further discussion determining that indoor rock climbing routes constitute useful articles; see supra notes 97-107 and accompanying text. For further discussion explaining how indoor rock climbing routes are sculptural works of art, see also infra notes 184-216 and accompanying text.

180. For further discussion noting the aesthetics of indoor rock climbing routes, see infra notes 184-216 and accompanying text.

181. See generally supra note 149 (exploring the inadequacies of the Star Athletica decision, most notably its lack of significant clarification regarding how new standard applies to three dimensional designs).

182. See 17 U.S.C. $§ 101$ (2020) (discussing what it means for feature to exist independently).

183. For further discussion of the background of the case, see infra notes 184-190 and accompanying text. 
ously copyrighted sculptural works of art consisting of rocks. ${ }^{184}$ While it was undisputed that these works had already qualified for copyright protection, the court had to determine "the breadth of protection to which the copyrighted work is entitled." 185 According to the court, such an "inquiry turns on "the range of creative choices than can be made in producing the work." "186 Following this logic, "[w] here there are 'only so many ways' to produce a work, such as a painting of a 'red bouncy ball on blank canvas,' the work's copyright protection is 'thin[...]' But where there is 'a wide range of expression (for example, there are gazillions of ways to make an aliens-attack movie),' the copyright protection is 'broad.'" 187

While the court acknowledged that copyright law does not protect three-dimensional wall sculptures, wave-like patterns, or "the use of rocks, or rock-shaped disks," the court did state that copyright law does protect "the original 'selection, coordination, and arrangement' of rocks and rock-shaped disks depicting the cyclical patterns of nature within large three-dimensional abstract wall sculptures."188 Most importantly, the court found that "the breadth of protection is broad, 'because there is a wide range of expression for selecting, coordinating, and arranging' the constituent elements in a stylized three-dimensional wall sculpture."189 Like the court in Mattel, Inc., v. MGA Entertainment, Inc., the court humor-

184. See Kevin Barry Fine Art Assocs. v. Ken Gangbar Studio, Inc., 391 F. Supp. 3d 959, 974 (N.D. Cal. 2019) (depicting subject works and accused works at issue in case).

185. Id. at 967 (citing Rentmeester v. Nike, Inc., 883 F.3d 1111, 1119-20 (9th Cir. 2018) (determining issue in case).

186. Id. (citing Rentmeester, 883 F.3d at 1120) (examining what level of creativity is required to achieve copyright protection).

187. See Malibu Textiles, Inc. v. Label Lane Int'l, Inc., 922 F.3d 946, 953 (9th Cir. 2019) (holding plaintiff's "selection, coordination, and arrangement" of floral elements in lace pattern were entitled to broad copyright protection); see also L.A. Printex Indus., Inc. v. Aeropostale, Inc., 676 F.3d 841, 850-51 (9th Cir. 2012) (finding broad copyright protection where there is "a wide range of expression for selecting, coordinating, and arranging floral elements in stylized fabric designs") (internal quotation marks omitted); see also Kevin Barry Fine Art Assocs., 391 F. Supp. 3d at 967 (citing Mattel, Inc. v. MGA Entm't, Inc., 616 F.3d 904, 913-14 (9th Cir. 2010) (determining depth of copyright protection).

188. See Kevin Barry Fine Art Assocs., 391 F. Supp. 3d at 967 (citing Malibu Textiles, 922 F.3d at 953) (protecting arrangement of rock wall sculptures).

189. See 17 U.S.C. $\$ 103$ (a) (2020) (providing copyright protection to compilations, defined as "a work formed by the collection and assembling of preexisting materials or of data that are selected, coordinated, or arranged in such a way that the resulting work as a whole constitutes an original work of authorship."); see also Kevin Barry Fine Art Assocs., 391 F. Supp. 3d at 967 (providing copyright protection for three dimensional sculpture). 
ously acknowledged that "there are 'gazillions of ways' to depict the cyclical patterns of nature, and the author was creatively unconstrained."190

Indoor rock climbing routes directly follow the facts of Kevin Barry. ${ }^{191}$ While the pieces of art in Kevin Barry may be argued to be clearly more purely artistic than an indoor rock climbing route, they are both rocks affixed to the surface of a wall, depicting wide ranges of expression in their arrangement. ${ }^{192}$

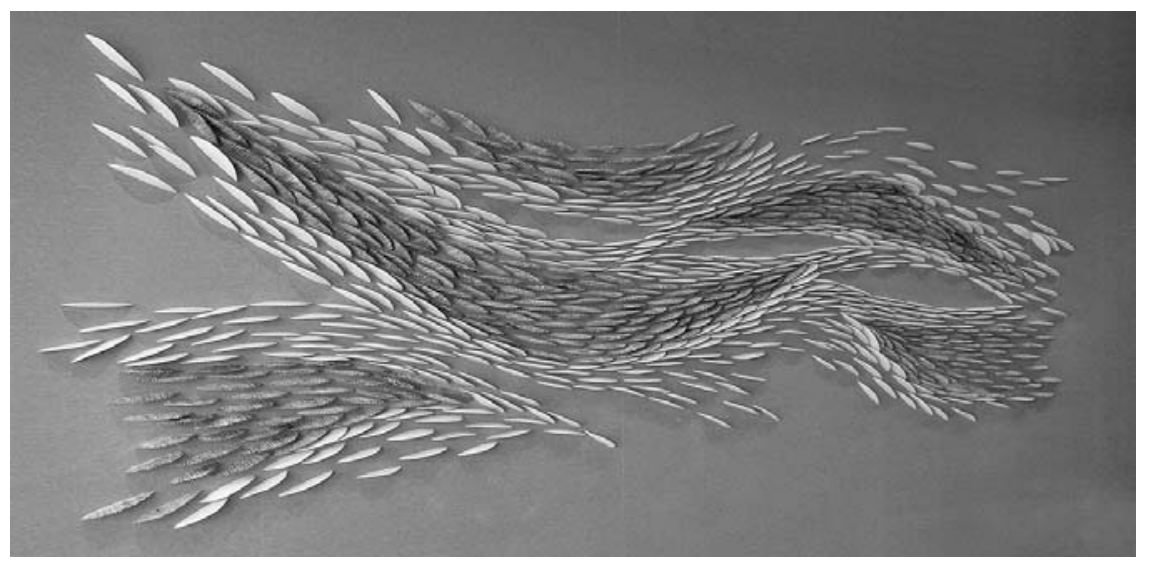

Figure 3: A work of art entitled Star, one of the works of art at issue in Kevin Barry. ${ }^{193}$ These rocks are clearly arranged in a wave-like pattern in an effort to be aesthetically pleasing. ${ }^{194}$

190. See Kevin Barry Fine Art Assocs., 391 F. Supp. 3d at 967 (citing Mattel, Inc., 616 F.3d at 913-14) (acknowledging wide range of expression in selecting elements of sculpture).

191. Compare id. at 974 (Figure 3 - depicting rock-based work of art from Kevin Barry) with Photograph: Christmas Tree Rock Wall (on file with author) (Figure 4depicting indoor rock climbing route set at The Gravity Vault Radnor).

192. For further discussion comparing indoor rock climbing routes to sculptural works of art in Kevin Barry, see infra notes 193-202 and accompanying text; see also Chris Brinlee Jr., The Noob's Guide to Rock Climbing, Outside (Mar. 16, 2016), https://www.outsideonline.com/2062326/beginners-guide-rock-climbing [https:/ /perma.cc/7JNT-ATBH] (stating that indoor rock climbing routes are often named, similar to conventional works of art); see also Greg Redlawsk, IMGUR (Oct. 4, 2020), https://imgur.com/gallery/tRrxtoU [https://perma.cc/5Z4P-CEV5] (depicting indoor rock climbing routes, located at Earth Treks, in Arlington, Virginia, set in manner that exemplifies artistic nature of indoor rock climbing routes).

193. See Kevin Barry Fine Art Assocs., 391 F. Supp. 3d at 974 (providing images of works in appendix).

194. See id. (comparing subject works to accused works). 
Tamerler: Indoor Rock Climbing: The Nuts and Bolts of Routesetting Copyrigh 2021]

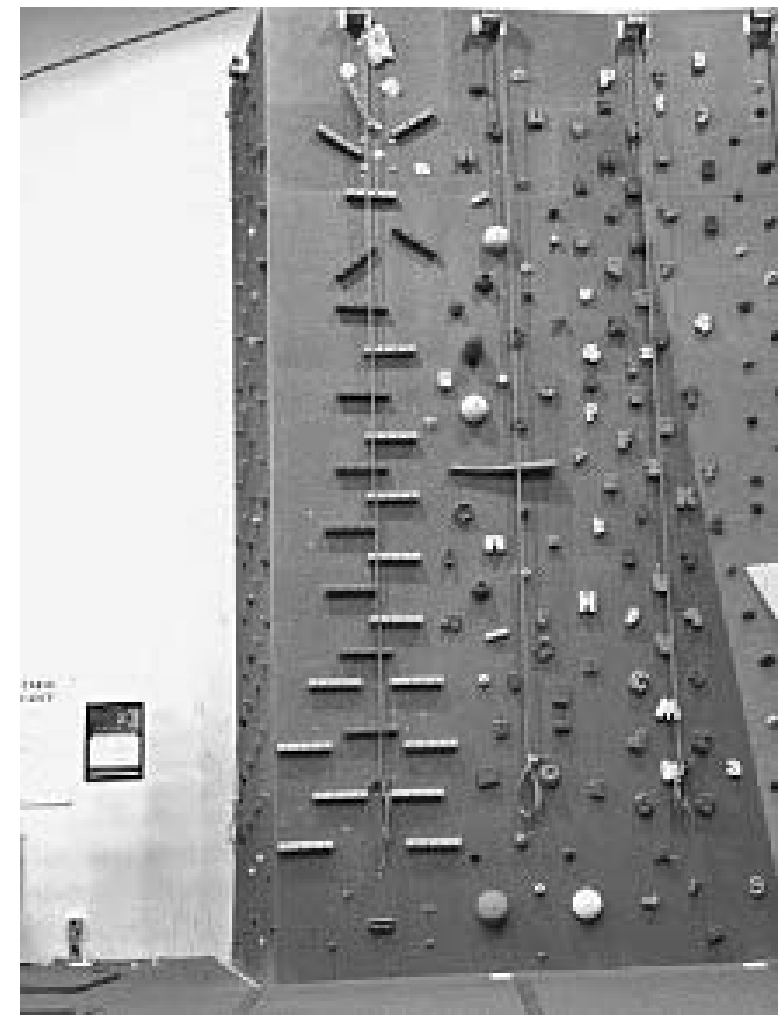

Figure 4: An indoor rock climbing route entitled "Christmas Tree," set by Routesetting Manager Kevin Tamerler at The Gravity Vault Radnor in Radnor, Pennsylvania. This route was set in the run up to the holiday season on the gym's "kids' wall." This route was designed to resemble a Christmas tree, while also being an easy to complete climbing route for children in the gym. ${ }^{195}$

The rocks in Kevin Barry's work, Star, were clearly arranged to be aesthetically pleasing. ${ }^{196}$ While the artistic elements of indoor rock climbing routes may not be as obvious to some, the bar for achieving copyright protection is low. ${ }^{197}$ As Melville Nimmer stated, "if a work might arguably be regarded as a work of art by any

195. See Interview with Kevin Tamerler, Routesetting Manager, The Gravity Vault Radnor, in Radnor, Pa. (Feb. 14, 2020) (discussing various routesetting projects).

196. See Projects, Kevin Barry Fine Art, https://kevinbarryfineart.com/ projects-all/ (last visited May 27, 2020) (displaying various decorative art projects).

197. See Feist Publ'ns, Inc. v. Rural Rel. Serv. Co., 499 U.S. 340, 345 (1991) (holding that "the requisite level of creativity is extremely low; even a slight amount will suffice."). 
meaningful segment of the population . . . then the work must be considered a work of art for copyright purposes."198

Like in Kevin Barry, the original selection, coordination, and arrangement of rock climbing holds by routesetters clearly points to indoor rock climbing routes being eligible for copyright protection. ${ }^{199}$ Every single aspect of constructing indoor rock climbing routes consists of art, from selecting the various holds, determining the angle of said holds, envisioning the method that must be utilized to complete the climb, and even naming the finished work. ${ }^{200}$ Marc Le Menestrel, a climber and author:

talks of the sport's quest for "movement and beauty" as well as its "intellectual casse-tête [puzzle]". The job of the route-setter is to make that experience possible and bring it out in its highest form. They are not just sculptors of walls; they are choreographers, forcing athletes into a vertical ballet in which they have to think on their fingertips and on their tippytoes. ${ }^{201}$

For example, Chris Danielson, chairman of the USAC Routesetting Committee, stated that he "very seriously consider[s] the aesthetic look of the boulder or route (the path of the line, the 'art' of how the holds interact with each other or the wall or the climber, and how the complete product looks on the wall)."202

198. 1 Melville B. Nimmer \& David Nimmer, Nimmer on Copyright $\S 2.08$ (C) (1) (a) (discussing low bar regarding originality requirement of copyright protection).

199. See generally U.S. Copyright Office, Compendium of U.S. Copyright Office Practices (2013) (available at https://www.copyright.gov/circs/circ14.pdf [https://perma.cc/5M9G-2YGX]) (discussing copyright standards associated with compilations).

200. See also John Burgman, High Drama: The Rise, Fall, and Rebirth of American Competition Climbing 311 (2020) (interviewing professional routesetter Mike Pont: “'In my heart, I love making climbing moves and making them feel just right . . . . [I] can't really describe what 'just right' means, but I know when I feel it that a route is just the way I want it. And I love that with a wrench and five minutes, I can take that thing apart - it's like pop-up art. It's a thing that I can create, and I take it away; it's there and then it's gone. I love that."').

201. See For Olympic climbing's route-setters, a blank wall is a canvas, THE EcONOMIST (Dec. 21, 2019), https://www.economist.com/christmas-specials/2019/12/ 21/for-olympic-climbings-route-setters-a-blank-wall-is-a-canvas [https://perma.cc/ D7JV-KE2A] (discussing routesetting for Tokyo 2020); see also Defining Body Tension, ROUTECRAFTER (Oct. 8, 2012), http://routecrafting.blogspot.com/2012/10/defining-body-tension.html [https://perma.cc/KJ4S-8MFV] (discussing body tension's role in setting routes).

202. See Kris Hampton, The Power Company (Feb. 13, 2012), https:// www.powercompanyclimbing.com/blog/2012/02/specialist-routesetting-withchris.html [https://perma.cc/3TAW-3S3C] (interviewing Chris Danielson, discussing how he approaches setting routes); see also Aesthetics in Routesetting: a Design 
Climbing walls are effectively blank canvases, waiting for routesetters to utilize an almost endless array of holds, techniques, and angles to construct their route; moreover, as prescribed in Star Athletica, the image of an indoor rock climbing route can easily be depicted on a canvas, achieving sufficient separability. ${ }^{203}$ The variables are almost endless; typical hold types consist of jugs, edges, crimps, slopers, pockets; each requires a different grip to hold, and depending on size and angle may require different body positions to properly utilize. ${ }^{204}$ A setter can envision various body positions for the climber to assume during the climb such as heel hooks, flagging, drop knees, smearing, stemming, laybacks, and mantles. ${ }^{205}$ In addition to this, routesetters plan other variables like hold angles, wall angles, hold color, grade level (from V0 to V16), hold brand and the combinations within said brand, and distance between holds and their types. ${ }^{206}$ Atomik Climbing Holds, a producer of indoor rock climbing holds, stocks "about 4,000 different shapes" and

Primer, Routecrafter (May 23, 2011), http://routecrafting.blogspot.com/2011/ 05/our-job-as-routesetters-is-to-set-stage.html [https://perma.cc/KSE2-YJEB] (summarizing aesthetic considerations to be taken when routesetting).

203. See Star Athletica, L.L.C. v. Varsity Brands, Inc., 137 S. Ct. 1002, 1012 (2017) ("Second, if the arrangement of colors, shapes, stripes, and chevrons on the surface of the cheerleading uniforms were separated from the uniform and applied in another medium-for example, on a painter's canvas-they would qualify as "two-dimensional . . . works of . . . art," \$101. And imaginatively removing the surface decorations from the uniforms and applying them in another medium would not replicate the uniform itself"); see also Silvertop Assocs. v. Kangaroo Mfg., 319 F. Supp. 3d 754, 765 (D.N.J. May 29, 2018) ("The Court finds that, if these features were separated from the costume itself and applied on a painter's canvas, it would qualify as a two-dimensional work of art in a way that would not replicate the costume itself"); see also Garrett Hulfish, Space-saving MoonBoard offers rock climbers plenty of training options, Digital Trends (May 27, 2017) https:// www.digitaltrends.com/outdoors/moonboard-climbing/ [https://perma.cc/ XB82-BYQN] (discussing MoonBoard, which as of publishing article had over 7,500 problems available despite MoonBoard's 140 holds remaining static upon installation); see also Setting for the Elite: PG'S Bret Johnston Talks Setting for USA Climbing Nationals, Planet Granite (Apr. 6, 2016), https://planetgranite.com/settingfor-the-elite-pgs-bret-johnston-talks-setting-for-usa-climbing-nationals / [https:// perma.cc/TG2Q-UNW9] (interviewing routesetter Bret Johnston, who states that "there's infinite possibilities of route setting movement . ...").

204. See Lindsay Walsh, Rock Climbing Holds: How to Climb Them, Mrora (Jan. 6, 2016), https://mpora.com/rock-climbing/climbing-holds-climb/ [https:// perma.cc/38EA-52DD] (displaying different indoor rock climbing holds, describing how they should be gripped to complete climb).

205. See Danaan Markey, Climbing Moves, Holds, E̋ Technique: The Beginner's Guide, 99Boulders, https://www.99boulders.com/climbing-moves-holds-and-technique [https://perma.cc/5UV3-TFG4] (last visited May 27, 2020) (displaying different movement techniques required to climb different types of holds).

206. See Kingdom Crowns Top Routesetter, Climbing Business Journal (Mar. 3, 2014), https://www.climbingbusinessjournal.com/kingdom-crowns-top-routesetter/ [https://perma.cc/9BTW-UBZX] (discussing first routesetting competition, showcasing variability associated with art). 
a large gym like Earth Treks in Washington DC "may stock 40,000 holds when a new shipment arrives."207 Marking tape and hold placement at "Psychadelia," an annual black light event at The Spot in Denver, Colorado showcase just how the boundaries of art and setting may be pushed; artists and setters come together to create large scale works of art utilizing tape and holds that glow under gym-wide black lights. ${ }^{208}$

The climber is the consumer of this art, experiencing the routesetter's creation through the act of climbing it. ${ }^{209}$ As stated by one routesetter:

Route setting isn't just putting pieces of plastic on a wall ... [I] t's how those pieces relate to one another to create a certain movement. Sometimes I pick shapes from the hold bin and I'm inspired by those shapes. Sometimes there's a specific sequence or movement I want to pursue that feels deeply personal, and that you're creating it with your hands and you're climbing it with your body. Routesetting is a way to share my personal climbing expression with other people. ${ }^{210}$

The difference in artistry is reflected in individual setter styles, which sometimes are even defined geographically: German routes

207. See E-mail from Kenny Matys, President, Atomik Climbing Holds, to Julie Tamerler (Jan. 29, 2020, 4:17 EST) (on file with author); see also Brendan Borrell, How the World's Most Difficult Bouldering Problems Get Made, Outside (Sept. 23, 2015), https://www.outsideonline.com/2017711/path-beta-flash-resistance-route-setters [https://perma.cc/2ACQ-VT27] (discussing routesetting at competitive level); see also Baby Supreme, So ILL, https:/ / soillholds.com/products/baby-supreme [https:/ /perma.cc/UW5T-AU3K] (last visited May 4, 2020) (displaying "Baby Supreme" sloper style hold, exemplifying how hold types are only limited by manufacturers' creativity).

208. See psychedelia 2019, The Spот, https://www.thespotgym.com/psychedelia [https://perma.cc/Q8MC-P562] (last visited May 4, 2020) (providing information regarding annual themed rock climbing event); see also KinetiK Climbing Products, Psychedelia 2018 at The Spot Gym, YouTube (Oct. 22, 2018), https:// www.youtube.com/watch?v=720hmD4Tesg [https://perma.cc/YE49-PVRF] (displaying routes, their artwork).

209. See Tonde Katiyo: Professional Route Setter, Heavy, https://tokyopowder.com/heavy/tonde.html [https://perma.cc/ZK2J-XL64] (last visited May, 27, 2020) (interviewing professional routesetter Tonde Katiyo: "For a long time now [my setting style] has been about emotion. Of course[,] I have passion about movement, and puzzles, playing and all the things that make climbing interesting but for me they are only building blocks to make people feel things. To me it is the most powerful gift to others: to feel things.").

210. See Aileen Imperial et al., Art Seen: The choreography of climbing, Crosscut (Feb. 7, 2020), https://crosscut.com/2020/02/art-seen-choreography-climbing [https://perma.cc/XTK5-DEGE] (featuring indoor rock climbing setters who explain how they set climbs). 
tend to be very technical regarding movement and engagement with holds, while French routes "are less about ergonomics and fluidity, and more about themed climbing which require difficult moves."211

While the movement clearly influences the artistic elements of the setting, in turn making it artistic, an important distinction needs to be made regarding the fact that it is the setting itself that is copyrighted, not the movement it inspires. ${ }^{212} 17$ U.S.C. Section 102(b) states that copyright cannot be extended "to any idea, procedure, process, system, method of operation, concept, principle, or discovery, regardless of the form in which it is described, explained, illustrated, or embodied in such work." 21317 U.S.C.S. Section 102(b) codifies the idea expression dichotomy, "under which 'every idea, theory, and fact in a copyrighted work becomes instantly available for public exploitation at the moment of publication.'"214 This theory aims to protect an author's right to original expression, but also "encourages others to build freely upon the ideas and information conveyed by a work." 215 Following this principle, courts have held that "copyright protection extends only to the forms in which ideas and information are expressed and not to the ideas and information themselves[,]" furthering the goals of the First Amendment. ${ }^{216}$

211. Are We Just Thugs?, MAD Rock TEAM Blog (Oct. 27, 2016), https:// madrockclimbing.wordpress.com/2016/10/27/are-we-just-thugs/ [https:// perma.cc/GZ6W-YZ69] (exploring different setting styles among various countries); see also John Burgman, High Drama: The Rise, Fall, and Rebirth of American Competition Climbing 288 (2020) ("The common phrase 'American style' had come to signify American boulderers' penchant for powerful movements of brute strength, often sustained throughout extended sequences, rather than the more graceful, balance-based 'European style.'”).

212. For further discussion establishing distinction between physical aesthetic, similarity, and movement, see infra notes 217-230 and accompanying text.

213. See 17 U.S.C. $§ 102$ (b) (2020) (discussing requirement that copyrighted material be fixed).

214. Bikram's Yoga Coll. Of India, Ltd. P'Ship. v. Evolation Yoga, Ltd. Liab. Co., 803 F.3d 1032, 1037 (9th Cir. 2015) (citing Golan v. Holder, 132 S. Ct. 873, 890 (2012)) (holding that sequence of yoga poses were not eligible for copyright protection).

215. Feist Publ'ns, Inc. v. Rural Rel. Serv. Co., 499 U.S. 340, 349-60 (1991) (discussing level of originality required for copyright protection).

216. L.A. News Serv. v. Tullo, 973 F.2d 791, 795 (9th Cir. 1992) (reiterating that only low level of creativity is required to achieve copyright protection). 
A. The Idea Expression Dichotomy Explored Through Bikram's Yoga College of India, L.P. v. Evolation Yoga, LLC

The tension inherent in the idea expression dichotomy is best expressed in Bikram's Yoga College of India, L.P. v. Evolation Yoga, LLC. ${ }^{217}$ In Bikram, the yoga teacher Bikram Choudhury created his own style of Hatha Yoga ("Bikram Yoga") utilizing "a particular arrangement of 26 'asanas' (poses) and two breathing exercises, which he called the 'Sequence.'"218 The Sequence had to be performed in precise order, for a specific amount of time, in a room heated to 105 degrees Fahrenheit. ${ }^{219}$ Choudhury "published and registered the [c] opyright in his book, Bikram's Beginning Yoga Class, which included descriptions, photographs, and drawings of how to perform the Sequence."220 Choudhury found that other yoga studios were employing his Bikram method, and he filed a complaint in the Central District of California alleging that "defendants Evolation Yoga, LLC . . . infringed 'Bikram's Copyrighted Works through substantial use of Bikram's Copyrighted Works in and as part of Defendants' offering of yoga classes.' "221 The court ultimately held that although Choudhury's book containing the Sequence was subject to copyright protection, the Sequence itself was not afforded the same protection because it consisted of a "system" and a "method," making it an idea not subject to copyright rather than the particular expression of an idea, which would be subject to copyright. ${ }^{222}$

In explanation, the court stated " $[\mathrm{t}]$ hat the Sequence may produce spiritual and psychological benefits makes it no less an idea, system, or process and no more amenable to copyright protec-

217. For further discussion comparing indoor rock climbing routes to Bikram and principles of copyright, see infra notes 218-230 and accompanying text.

218. Thomas Huthwaite, Copyright law not flexible enough to protect Bikram Yoga Sequence, BALDwins (Oct. 15, 2015), https://www.baldwins.com/news-resources/ news/copyright-law-not-flexible-enough-to-protect-bikram-yoga-sequence [https:// perma.cc/HPW5-NXAT] (discussing court's ruling in Bikram).

219. See id. (noting Sequence had to be performed over course of 90 minutes).

220. Id. (stating background facts regarding attempted copyright of Sequence).

221. Bikram's Yoga Coll. Of India, Ltd. P'Ship. v. Evolation Yoga, Ltd. Liab. Co., 803 F.3d 1032, 1036 (9th Cir. 2015) (quoting from Bikram's complaint).

222. See id. at 1041 ("By claiming copyright protection for the Sequence as a compilation, Choudhury misconstrues the scope of copyright protection for compilations. As we have explained, the Sequence is an idea, process, or system; therefore, it is not eligible for copyright protection. That the Sequence may possess many constituent parts does not transform it into a proper subject of copyright protection. Virtually any process or system could be dissected in a similar fashion."). 
tion."223 Additionally, the Sequence's supposedly beautiful and graceful arrangement of postures was not a basis for copyright protection, and such beauty "does not permit one who describes it to gain, through copyright, the monopolistic power to exclude all others from practicing it." 224 Finally, the court in Bikram found that the Sequence did not consist of a copyrightable compilation nor choreographic work. ${ }^{225}$ The court stated:

The Sequence is not copyrightable as a choreographic work for the same reason that it is not copyrightable as a compilation: it is an idea, process, or system to which copyright protection may "[i]n no case" extend. 17 U.S.C. $\S 102$ (b). We recognize that the Sequence may involve "static and kinetic successions of bodily movement in certain rhythmic and spatial relationships." So too would a method to churn butter or drill for oil. That is no accident: "successions of bodily movement" often serve basic functional purposes. Such movements do not become copyrightable as "choreographic works" when they are part and parcel of a process. Even if the Sequence could fit within some colloquial definitions of dance or choreography, it remains a process ineligible for copyright protection. ${ }^{226}$

While parallels may be drawn between the practice of yoga and indoor rock climbing, there are important differences between the two disciplines for the purpose of securing copyright protection. ${ }^{227}$ Bikram ultimately failed in protecting the Sequence because it consisted of an idea, system, or process; in contrast, indoor rock climbing routes are fixed tangible pieces of sculpture that result in an

223. See id. at 1040 (explaining why sequence may not be eligible for copyright protection).

224. Id. (elaborating that sheer beauty does not warrant copyright protection).

225. See id. at 1041 (concluding that Sequence was not eligible for copyright protection); see also generally Kara Krakower, Finding the Barre: Fitting the Untried Territory of Choreography Claims into Existing Copyright Law, 28 Fordham InTEll. Prop. Media \& ENT. L.J. 671 (2018) (exploring potential copyright protection for choreography).

226. Bikram's Yoga Coll. Of India, 803 F.3d at 1044 (providing reasoning for denying copyright protection for Sequence) (citation omitted).

227. For further discussion exploring differences between indoor rock climbing and yoga, see infra 228-230 and accompanying text. 
idea, system, or process of movement. ${ }^{228}$ Bikram proves that a setter cannot copyright a specific method of movement for a climb, such as a heel hook or a gaston. ${ }^{229}$ Despite this, however, a routesetter would still be able to copyright the arrangement and sequence of holds placed upon a wall that result in certain movements. ${ }^{230}$

\section{B. Physical Aesthetic Similarity and Movement: A Visual Representation of Copyright Protection}

Bikram, when read in conjunction with Kevin Barry, reinforces the idea that the physical sculpture of an indoor rock climbing route is subject to copyright; this principle is displayed in the table below. ${ }^{231}$ The $\mathrm{X}$-axis represents a change in movement between climbs (with movement absent physical attributes encompassed in Bikram), while the Y-axis represents a change in physical aesthetics to the physical sculpture of the climb (as discussed in Kevin Barry).

Kevin Barry

(change in physical aesthetic similarity (PAS))

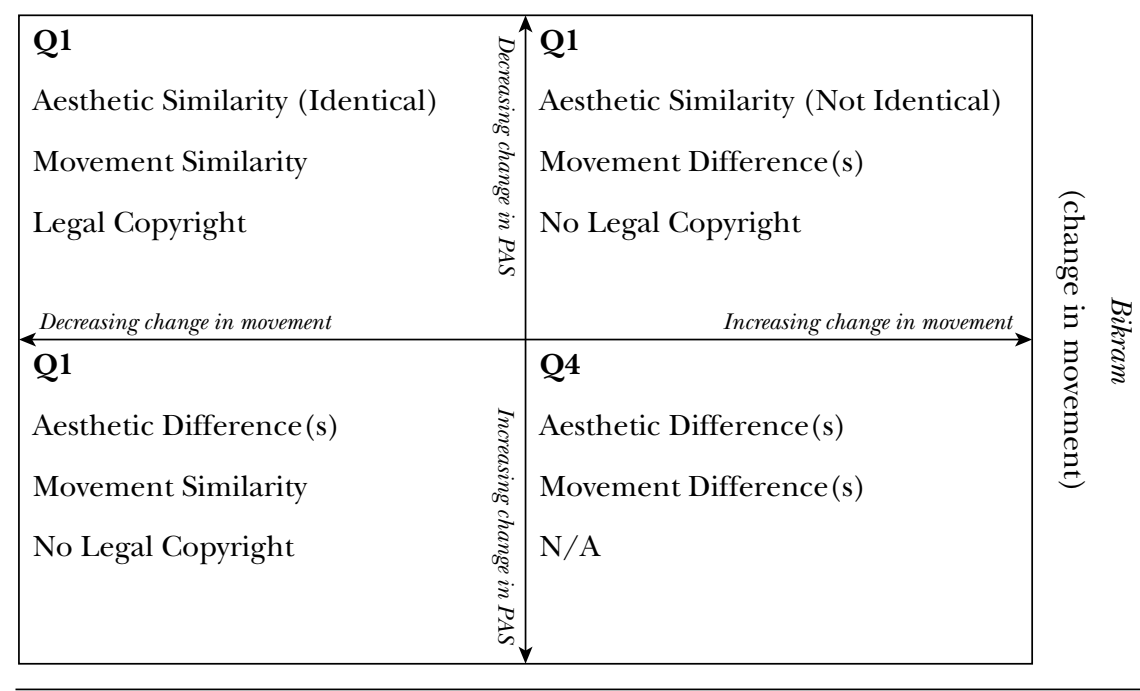

228. See Bikram's Yoga Coll. of India, Ltd. P'ship v. Evolation Yoga, Ltd. Liab. Co., 803 F.3d 1032, 1044 (9th Cir. 2015) (finding that Bikram's Sequence was not eligible for copyright protection).

229. See generally 10 Advanced Climbing Moves, Beta Together (Dec. 19, 2017), https://betatogether.com/11-advanced-climbing-moves/ [https://perma.cc/ 3QNG-HQXQ] (discussing how to perform different advanced climbing movements on indoor routes).

230. For further discussion of how copyright applies to physical arrangement as regards indoor rock climbing routes, see supra notes 84-92, 184-202 and accompanying text.

231. See supra table entitled Kevin Barry (displaying interplay between physical similarity, change in movement). 


\section{Q1}

Q1 represents an indoor rock climbing route that identically copies a protected route: two climbs that are aesthetically the same, utilizing the same movements, and both in existence while the original climb is subject to a copyright. ${ }^{232}$ This type of situation warrants the most protection; a pure 1:1 copy of a climb is not only disrespectful towards the individual who set that climb, but also to the gym where the original climb was set. ${ }^{233}$ The setter who created the original, protected climb would rightfully deserve to be able to protect their own labor and work. ${ }^{234}$ Additionally, Q1 is the only realistic situation in which a routesetter can expect to successfully enforce their hypothetical copyright. As discussed previously, this type of enforcement is only possible because of Star Athletica's new rule for separability. 235

\section{2. $Q^{2}$}

A copied climb according to the terms listed in Q2 would be in violation of copyright. Although the movement associated with completing the climb would be different, the aesthetic elements (the appearance of the holds arranged in a particular way) would still be identical. The infringing routesetter could utilize a hold that looks identical to one in the copyrighted climb, but there may be millimeters of difference within the hold profile or texture of the hold that would completely influence how the climb is to be completed. ${ }^{236}$ As exemplified by Bikram, this difference in movement does not save an infringing climb from violation; it is the fixed, physical sculpture of the indoor rock climbing route that is copyrighted, not the movement that it produces. ${ }^{237}$ Potentially, this climb could be under an enforceable copyright, as courts may not view a few millimeters of difference or a change of angle that is only

232. For further discussion of golf courses copying features from other golf courses, see infra notes 263-273 and accompanying text.

233. See supra note 255 (exemplifying how setting became formalized profession only recently, highlighting need to protect its current status).

234. See id. (further discussing copyright issues and golf).

235. For further discussion of the new standard for separability established by Star Athletica, see supra notes 131-153 and accompanying text. holds).

236. Compare Figure 5, Figure 6 below (depicting set of indoor rock climbing

237. See Bikram's Yoga Coll. of India, Ltd. P'ship v. Evolation Yoga, Ltd. Liab. Co., 803 F.3d 1032, 1044 (9th Cir. 2015) ("The Sequence is not copyrightable as a choreographic work for the same reason that it is not copyrightable as a compilation: it is an idea, process, or system to which copyright protection may '[i]n no case' extend. 17 U.S.C. § 102(b).”). 
visible from certain angles as sufficiently aesthetically unique. ${ }^{238}$ However, for the climber utilizing those holds, five millimeters represents the difference between an expert level of difficulty and a moderate level of difficulty. ${ }^{239}$ This type of change results in vastly different levels of difficulty, and as a result, changes how climbers position their bodies. ${ }^{240}$ Regardless, such a climb would still likely be in violation of copyright because it is the aesthetic similarities that matter. ${ }^{241}$ It would, however, be easy in many cases for a routesetter to alter the climb aesthetically while maintaining the original movement patterns by swapping the offending holds with other holds that have similar usable surface areas but differ in their outward appearance. ${ }^{242}$

238. See generally Moon Hee Lee, Seeing's Insight: Toward a Visual Substantial Similarity Test for Copyright Infringement of Pictorial, Graphic, and Sculptural Works, 111 Nw. U.L. Rev. 833 (2017) (discussing current substantial similarity tests regarding visual works, advocating for new analysis rooted in science).

239. See generally Michael Der Manuelian, The Role of the Expert Witness in Music Copyright Infringement Cases, 57 FordHAM L. REv. 127 (1988) (discussing role of expert witnesses in determining if copyright violations occurred in music. Similarly, litigation regarding indoor rock climbing routes would require expert witnesses to discuss similarities, differences regarding indoor rock climbing holds); see also Joe Robinson, What Happened to the Speed Holds?, Climbing Business Journal (Jan. 11, 2016), https://www.climbingbusinessjournal.com/what-happened-to-thespeed-holds/ [https://perma.cc/T2RZ-DE9L] (discussing how millimeters of difference in holds may influence performance).

240. See Types of Holds and How to Use Them, Sportrock (Aug. 15, 2017), https://sportrock.com/types-of-holds-and-how-to-use-them/ [https://perma.cc/ BP9G-BFNA] (comparing different indoor rock climbing holds; notably, holds associated with higher difficulty levels, such as crimps, have shallower profile, especially when compared to holds associated with lower levels of difficulty, like jugs; see also id. (depicting various holds); see also Joe Robinson, What Happened to the Speed Holds?, Climbing Business Journal (Jan. 11, 2016), https:// www.climbingbusinessjournal.com/what-happened-to-the-speed-holds/ [https:// perma.cc/7BWW-5492] (discussing the use of speed holds in climbing gyms).

241. For further discussion of the importance of physical aesthetic elements, see supra notes 213-229 and accompanying text.

242. See Interview with Kevin Tamerler, Routesetting Manager, The Gravity Vault Radnor, in Radnor, Pa. (June. 4, 2020) (discussing routesetting process). 


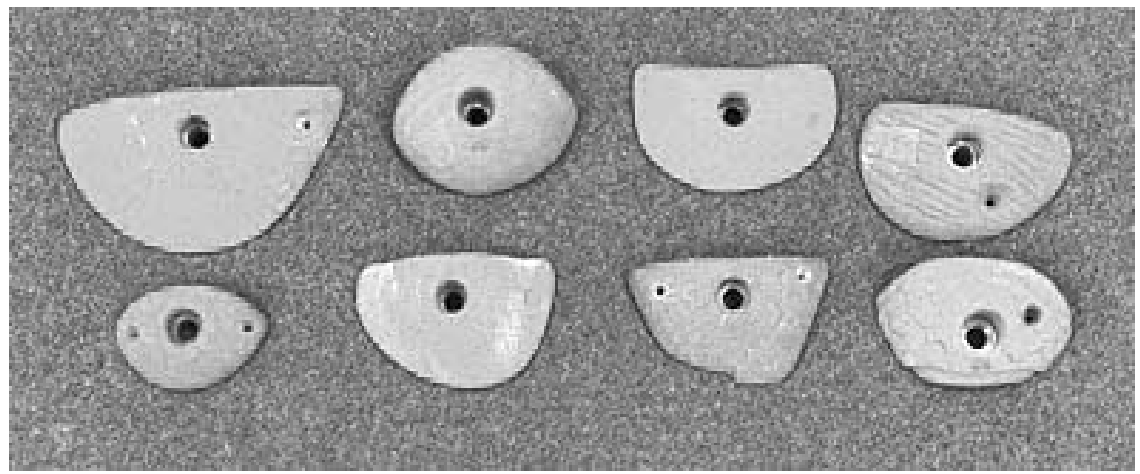

Figure 5: Above are indoor rock climbing holds that, when viewed straight on, share aesthetic similarity in color and shape.

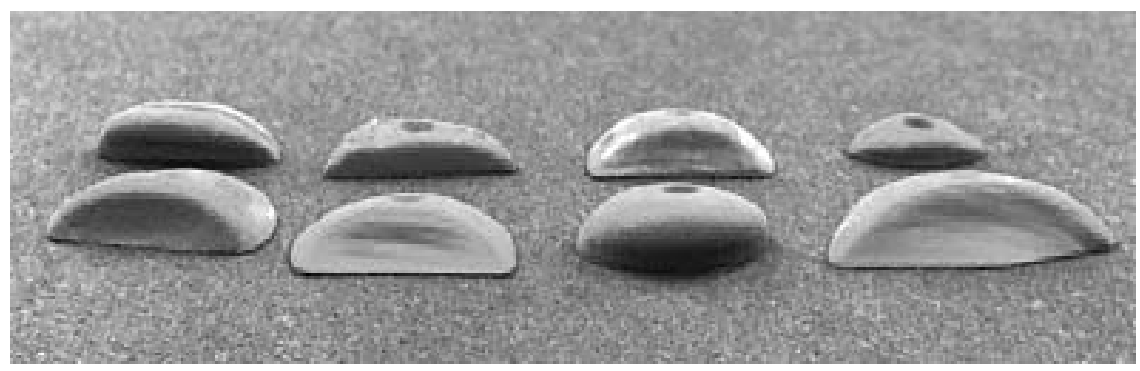

Figure 6: Above are the same holds as Figure 5, shown in profile. In profile, it is clear that each hold differs in function; each hold has a different depth of grippable area, texture, curvature, and angle.

\section{Q3}

This type of indoor rock climbing route would not infringe on a copyright because its rock placement would contain aesthetic difference(s), despite the fact that its movements are similar or functionally identical to the original copyrighted climb. This could be achieved with the use of holds that have the same usable, grippable surface area, but differ in the aesthetic decorations applied to the non-useful surface of the hold. ${ }^{243}$ For example, two crimp holds may have identical fifteen millimeter flat edges that are gripped by the climber, but a non-useable smooth surface could extend below the edge for a varied distance, looking very different. ${ }^{244}$ Although this route would have movement similarity, it would not be eligible holds).

243. Compare Figure 7, Figure 8 below (depicting set of indoor rock climbing

244. See id. (depicting indoor rock climbing holds). 
for copyright because, as discussed previously, it would not have the necessary aesthetic similarity. ${ }^{245}$

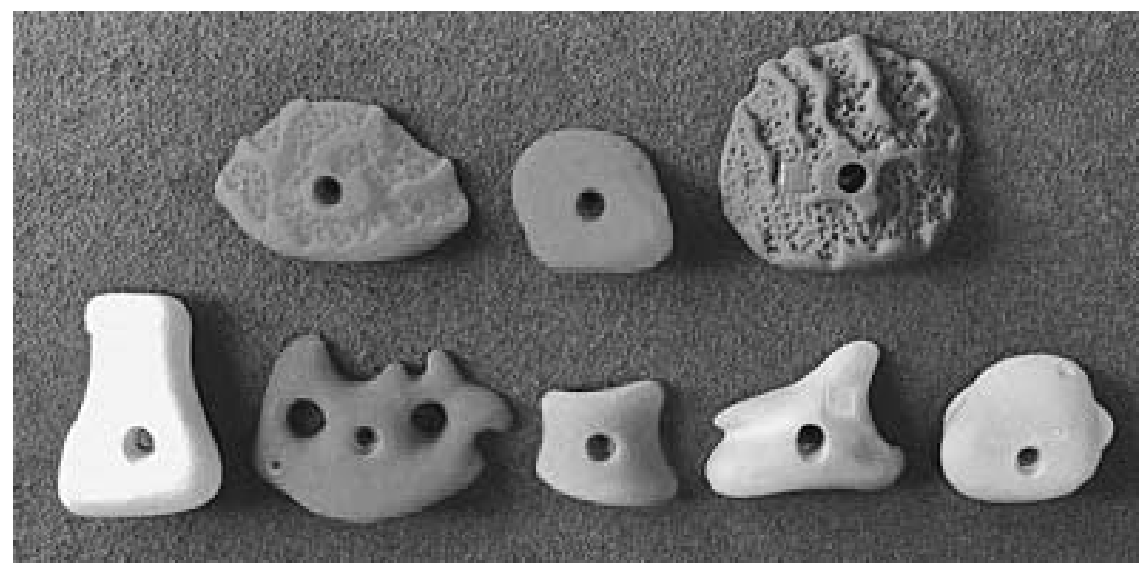

Figure 7: Above are indoor rock climbing holds that differ in appearance when viewed straight on.

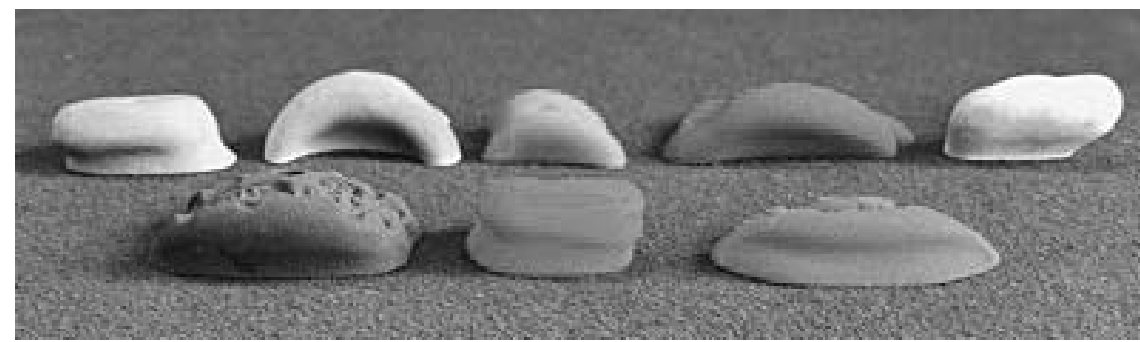

Figure 8: Above are the same holds as Figure 7, shown in profile. In profile, it is apparent that they are all very similar in function; they are all slightly "juggy" holds with similar amounts of grippable surface area and depth. ${ }^{246}$

\section{4. $Q^{4}$}

This represents a completely original climb that is aesthetically distinct from a protected climb and utilizes different movements. The issue of legal copyright is irrelevant because this climb is unrelated to a copyrighted climb. Scholars have noted that expanded separability may result in a "race to the copyright office," rewarding those who try to copyright every permutation of an indoor rock

245. For further indication depicting grouping of indoor rock climbing holds with aesthetic similarity, see supra Figure 5.

246. See Types of Holds and How to Use Them, supra 240 (showing various types of holds, technique to climb them). 
climbing route. ${ }^{247}$ While such strategies may appear to be blatant anti-competitive efforts, the above table and corresponding explanations show that this would not be the case if courts enforce the copyright with an eye toward how climbers and gyms utilize routes. ${ }^{248}$ Because of the ease with which a climb could be altered aesthetically by simply changing out offending holds for functionally identical holds with different appearances, most copyright claims would result in a mild inconvenience. ${ }^{249}$ The only situation in which a gym or setter would go to court to preserve the original aesthetic appearance of the climb would be if they were intentionally attempting to copy the aesthetic appearance of the earlier climb in order to pass their copy publicly as an exact copy of the original. $^{250} \mathrm{Q} 1$, or a 1:1 copy, is the only situation that may be successfully litigated, and which would potentially be worth litigation. Importantly, indoor rock climbing routes are sculptural works that deserve copyright protection, but pre-Star Athletica, this would have not been possible. One may argue that it would be too "easy" to receive copyright protection for an indoor rock climbing route, even the ability to precisely copy a route would require a perfect storm of circumstances: the copying setter would need to have access to the same holds, be setting the same wall area and angles, and happen to make the same choices. Considering how many variables exist within indoor routesetting, the odds of a climb being

247. See Lili Levi, The New Separability, 20 VAnd. J. Ent. \& TEch. L. 709, 709-10 (2018) ("By focusing only on the protectability of the particular designs at issue in an infringement case, neither Star Athletica's new separability test nor copyright's other limiting doctrines address the elephant in the room: the possible market impact of an aggregation of copyright registrations of design features with slight variations. Varsity Brands registered two hundred copyrights in variations of its similar uniform designs. Should this be considered a problem in its market? A strategy of covering the design field can have powerful foreclosure effects on markets for useful works. . . . [T]hus, perhaps the most significant threat today to what Congress sought to protect by adopting the separability requirement lies not in the individual copyright registration for an aesthetic design or the individual infringement suit but in the business strategy of copyright aggregation for aesthetic elements of functional works in some types of markets.").

248. See generally Der Manuelian, supra note 239 (emphasizing importance of expert witnesses for copyright infringement litigation). holds).

249. See Tamerler, supra note 242 (discussing ease of switching out offending

250. See generally Pebble Beach Co. v. Tour 18 I Ltd., 155 F.3d 526 (5th Cir. 1998) (deciding case in which Plaintiff golf course deliberately copied famous Defendant golf courses in effort to attract customers); see also Illinois Tool Works, Inc. v. Rust-Oleum Corporation, 955 F.3d 512, 514-15 (Cir. 5th 2020) ("we are guided by the non-mandatory, non-exclusive factors in Pebble Beach Co. v. Tour 18 I Ltd., 155 F.3d 526, 554 (5th Cir. 1998), abrogated on other grounds by TrafFix Devices, Inc. $v$. Mktg. Displays, Inc., 532 U.S. 23 (2001).”). 
accidentally "copied" are slim. ${ }^{251}$ However, if courts were to interpret the copyright broadly, as an interdiction against all similar climbs, then they could create issues where the range of climbs that can be set is artificially limited. ${ }^{252}$

\section{Conclusion: A New Future}

Indoor rock climbing has already reached the mainstream and is poised to become even more popular with the arrival of the Tokyo Olympics, where rock climbing will appear as an Olympic sport for the first time. ${ }^{253}$ With this increased focus on the sport comes the creation and rise of climbing celebrity; this is evident with professional rock climber Alex Honnold, who became the first individual to climb El Capitan without safeguards, as documented in the Academy Award winning documentary Free Solo. ${ }^{254}$ Today,

Honnold, an in-demand speaker on the corporate/TED/

VC circuit, participated in a discussion on risk management for a group of venture capitalists (the partner who moderated is a big ice climber). Now, well after dark, he is at a soon-to-open franchise of Planet Granite, part of the country's largest group of climbing gyms (for which he is a board member), near an industrial park off the freeway in Fountain Valley, California, modeling fashion pants. ${ }^{255}$

As indoor rock climbing becomes more lucrative, so will routesetting. ${ }^{256}$ For example, celebrity climber Chris Sharma "has

251. For further discussion listing variables that influence outdoor climbing routes, see supra notes 202-206 and accompanying text.

252. See Louis Menand, Crooner In Rights Spat, The New Yorker (Oct. 13, 2014), https://www.newyorker.com/magazine/2014/10/20/crooner-rights-spat [https://perma.cc/BW9X-46FV] (discussing issues with copyright law, internet, resulting in copyright being "too effective").

253. See Brendan Blanchard, Olympic Climbing Survey: 15 Pro Climbers Weigh In, Climbing (Sept. 23, 2016), https://www.climbing.com/news/olympic-climbingsurvey-15-pro-climbers-weigh-in/ [https://perma.cc/YWR5-VG7E] (interviewing Paige Claassen, who states: "[o]pinions aside, climbing is growing rapidly and our spot in the Olympics is about to supercharge that growth.").

254. See Sam Wollaston, "It's sort of the extreme": Free Solo's Alex Honnold on rockclimbing without ropes, THE GUARDiAn (Feb. 26, 2019), https:// www.theguardian.com/sport/2019/feb/26/free-solo-alex-honnold-climb-elcapitan-without-ropes-interview [https://perma.cc/4MP3-JJGY] (interviewing Alex Honnold about his free soloing El Capitan, in Yosemite, California).

255. Caroline McCloskey, Alex Honnold Takes Us into the Great Indoors, GQ (Jan. 21, 2020), https://www.gq.com/story/alex-honnold-great-indoors [https:// perma.cc/2X2T-ZX68] (discussing Alex Honnold's life after climbing El Capitan, rise of rock climbing in United States).

256. See infra note 261 (discussing increased formalization of routesetting profession and industry). 
also branched into business-designing shoes for Evolv, opening three rock gyms[ including one simply called "Sharma". . .] and recently signing on as a face of Ralph Lauren's Red Extreme cologne."257 As rock climbers become "brands" others will want to emulate them, wondering where people like Sharma train, paying attention to who sponsors them, and what techniques they use. ${ }^{258}$ The Olympics and its qualifying events will dominate public consciousness of the sport, and while actual Olympic routes will likely not be copied by gyms because of their high difficulty, gyms will have incentive to ride the coattails of popular Olympic climbs and setters. ${ }^{259}$ For example, a gym advertising that they have climbs set by a "celebrity" setter, or that climbs are the same as ones that were set at a qualifying event would be highly attractive to customers. ${ }^{260}$ While some may dispute the literal value of indoor rock climbing

257. See Sharma Climbing BCN, SHARMA, http://www.sharmaclimbingbcn.com/ en/ [https://perma.cc/W3VA-X4EW] (last visited May 30, 2020) (providing information regarding Chris Sharma's indoor rock climbing gym in Barcelona, Spain); see also Seth Heller, Chris Sharma Sends the Corporate Ladder, Outside (Jan. 22, 2018), https://www.outsideonline.com/2274966/chris-sharma-climbs-corporate-ladder\#close [https://perma.cc/S8B5-H2H3] (interviewing professional climber Chris Sharma about his career).

258. See A Very Grand Opening, First Ascent Climbing \& Fitness (Jan. 5, 2016), https://firstascentclimbing.com/a-very-grand-opening/ [https:// perma.cc/2J9X-J5BZ] (recounting Chris Sharma's visit to local indoor rock climbing gym, providing autographs, engaging with fans).

259. See id. (discussing professional rock climber's impact on local indoor rock climbing gym); see also Fred Bowen, Sport climbing moves into the spotlight with an Olympic debut in 2020, The Washington Post (Dec. 18, 2019), https:// www.washingtonpost.com/lifestyle/kidspost/sport-climbing-moves-into-the-spotlight-with-an-olympic-debut-in-2020/2019/12/18/2163f210-1b71-11ea-87f7f2e91143c60d_story.html [https://perma.cc/H5N2-VWJ4] (discussing indoor rock climbing at Olympics in manner aimed at children, highlighting how excitement regarding indoor rock climbing events may influence later generations); see also New Olympic sports adjust to the limelight, THE Economist (Dec. 31, 2019), https:// www.economist.com/the-world-in/2019/12/31/new-olympic-sports-adjust-to-thelimelight [https://perma.cc/ZGL5-V4PA] (discussing increase of indoor rock climbing walls in Britain, fact that The International Olympic Committee (IOC) specifically added indoor rock climbing to Olympics in effort to appeal to "younger crowd").

260. See John Burgman, High Drama: The Rise, Fall, and Rebirth of AmeriCAN Competition Climbing 19 (providing context regarding how American rock climbing culture differed in comparison to Europe's: "The appeal [of rock climbing in the 1980s] was not only in the climbing competitions themselves, but how the competitors were respected around Europe. The top European climbers . . . were treated like rock stars in their home countries, where they gained celebrity status. They gave frequent television interviews, appeared in advertisements, and developed throngs of adoring fans. This contrasted greatly with the counterculture roots and rock-bum stigma still associated with climbers in the United States.”). 
routes, it is important for the industry to understand the breadth of potential copyright protection before the issue arises. ${ }^{261}$

A parallel can be seen when examining golf course designers and architects, like Jack Nicklaus, Bobby Jones, and others, who have created golf courses designs. ${ }^{262}$ While the golf course designs are able to be copyrighted under "technical drawings, including architectural plans[,]" this only protects the copying of the plans themselves and not what such plans actually create. ${ }^{263}$ Indoor rock climbing routes are sculptural artistic creations with utility; similarly, golf courses utilize bodies of water, sand traps, or even lighthouses to be aesthetically pleasing while also shaping the course itself. ${ }^{264}$ Golf courses have already been imitated as shown in Pebble Beach Co. v. Tour 18 I Ltd., a consolidated case in which the defendant, Tour 18, deliberately copied features of famous golf courses. ${ }^{265}$ Among others, Tour 18 copied the eighteenth hole of Harbour Town Golf Links, known for a featuring a red and white lighthouse. ${ }^{266}$ By copying this lighthouse and overall hole design, Tour 18 was able to piggyback off of the brand value created by

261. See id. at 310-11 ("[A goal] for the United States' competition enthusiasts ... was the career opportunities for routesetters. Tim Steele would recall asking his Ohio employer . . . about the potential for advancement as a routesetter in the late 1990 s, only to be told by the gym at the time that the options were limited. A little more than a decade later, largely due to the multilevel routesetting certification course of USA Climbing, routesetters could find far more lucrative options and a more accessible communal network. 'The modern gyms are paying health care, and you have a salary, and people are obviously making a living off of it,' Steele says of routesetting in the present day. 'Back then, there weren't that many routesetters because it just wasn't a career-oriented thing." ).

262. See Top 100 Architects, Top 100 Golf Courses, https:// www.top100golfcourses.com/architects [https://perma.cc/3KUF-W5PV] (last visited Oct. 13, 2020) (listing famous golf course designers).

263. See 17 U.S.C. $\$ 101$ (2020); see also Robert D. Howell, Tee'd Off - Golf Course Designers Score Double Bogey in Search for Protection of Their Hole Designs, 5 J. INTELL. Prop. L. 337, 338-39 (1997) (exploring potential copyright protection for golf courses).

264. See Howell, supra note 263, at 345 (discussing specific aesthetic, functional features of golf courses, specifically lighthouse at Harbour Town's eighteenth hole).

265. See id. at 349-50 (detailing how Tour 18 researched, traveled, videotaped, took aerial photographs and videos of holes they planned to copy; "[f]or example[,] . . . Tour 18 even built a replica of the lighthouse present on Harbour Town's Hole No. 18. Golfers who have played both the Tour 18 copied course and the originals say that most of its features are better than ninety-five percent accurate. Tour 18 has even gone so far as to copy the original holes' mowing patterns for the greens and fairways.").

266. See Pebble Beach Co. v. Tour 18 I Ltd., 155 F.3d 526, 534 (5th Cir. 1998) (discussing copying of famous features of various golf courses). 
Harbour Town Golf Links. ${ }^{267}$ Tour 18's efforts were popular with customers and highly profitable; they "cleared profits of over 1.7 million dollars on an initial investment of 5 million dollars." 268 While the plaintiff golf course owners sued for trademark infringement, among other claims, the court throughout mentioned that there was no copyright protection available for the various golf course designs that were copied. ${ }^{269}$ Robert D. Howell explored the potential for copyright protection of golf courses in 1997, ultimately finding that they were useful articles that could not pass a pre-Star Athletica separability analysis. ${ }^{270}$

Clearly, golf course architecture differs greatly compared to indoor rock climbing routes. Features put into place within courses are not always functional in terms of determining or adding to the difficulty of the hole, so subsequent copyright protection would require a different analysis. ${ }^{271}$ However, aesthetic elements that are meant to be used within the course, like a hole that is contained within a miniature lighthouse, as usually utilized within mini golf courses, may be analyzed within the same structure proposed in this note. ${ }^{272}$ Overall, indoor rock climbing routes uniquely combine artistic, aesthetic elements with utility, making them excellent candidates for copyright protection. ${ }^{273}$

As of the time of this writing, there have been no copyrights filed for indoor rock climbing routes; as a result, there have been

267. See About Tour 18, Tour 18, [https://www.tour18golf.com/about https:/ /perma.cc/NA2R-6C2R] (last visited May 30, 2020) ("At Tour 18 Golf Course we've painstakingly reproduced the most renowned holes in the history of golf. Just imagine yourself playing the same challenging holes that have determined the outcome of tournaments such as the US Open, The Masters, The Tour Championship, and the PGA Championship.").

268. See Howell, supra note 263, at 351 (discussing success of Tour 18).

269. See Pebble Beach Co. v. Tour 18 I Ltd., 155 F.3d 526, 533-34 (5th Cir. 1998) (stating that there was no copyright for design of Pebble Beach's fourteenth hole, discussing design of Pinehurst's third hole).

270. See Howell, supra note 263, at 342-47 (applying pre-Star Athletica analysis of golf courses, concluding that they are not eligible for copyright protection because they fail separability analysis).

271. See generally John Nivala, The Landscape Art of Daniel Urban Kiley, 29 WM. \& Mary Envtl. L. \& Pol'y Rev. 267 (2005) (discussing how landscape architecture remains unprotected under copyright law, advancing view that it should be considered visual art); see also Howell, supra note 263, at 345 (concluding that copyright was "not a feasible method of protection" for golf holes, even if they "contain beautiful artistic creations of landscape design," because "most hole features serve a dual purpose of ornamentation and usefulness.").

272. For further discussion of the general framework of copyrighting indoor rock climbing routes, see supra notes 84-183 and accompanying text.

273. For further discussion of how the utilitarian and aesthetic are intertwined regarding indoor rock climbing routes, see supra notes 33-40, 74-80, 117-122, 191-216. 
no lawsuits filed regarding these types of copyright claims. ${ }^{274}$ However, this does not mean that such a lawsuit will never be filed; the indoor rock climbing industry is undergoing rapid change as the number of gyms and participants expand rapidly across the United States and the world. ${ }^{275}$ This participation will only accelerate in the near future as the first Olympic medals are awarded to rock climbers in the upcoming Tokyo Olympics. ${ }^{276}$ With indoor rock climbers and the routes they climb appearing on television screens across the world, millions of viewers will be exposed to the sport, and many of them will choose to explore it themselves at their local gym. ${ }^{277}$ The combination of increasing competition between multiple gyms within a local market, and a vast pool of new or more enthusiastic customers after the Olympic games, will lead gyms and routesetters to compete aggressively over the quality of the routes that are set in their gyms. ${ }^{278}$ At the end of the day, indoor rock climbing gyms are made up of one thing: routes. ${ }^{279}$ With a view towards this rising competitive atmosphere routesetters, gym owners, managers, industry organizations, and their counsel should seek to understand and explore their rights regarding their intellectual property in the routes they set. ${ }^{280}$ Additionally, stakeholders

274. See supra note 2 (outlining current legal discussion regarding indoor rock climbing).

275. For further discussion explaining the increased popularity of indoor rock climbing, see supra notes 32-43, 253-260 and accompanying text.

276. See id. (explaining increasing popularity of indoor rock climbing).

277. See id. (discussing current accessibility of sport to those who are not "hardcore" climbers).

278. See Portfolio, Tengram Capital Partners, https://www.tengramcapital. com/tengram-capital-partners-portfolio.html [https://perma.cc/7ZF9-8HGF] (last visited May 30, 2020) (detailing El Cap Holdings as investment in portfolio, alongside brands like Algenist (skincare), Cos Bar (luxury beauty retailer), Lime Crime (cosmetics)); see also Jason Blevins, The indoor climbing industry is booming on a foundation bolted to Colorado's Front Range, The Colorado Sun (Dec. 5, 2019), https://coloradosun.com/2019/12/05/colorado-indoor-climbing-gym-industrybooming/ [https://perma.cc/XC9U-4AW3] (discussing growth of indoor rock climbing gym industry, spurred by significant investments made by various private equity firms. Brooklyn Boulders signed $\$ 48.75$ million deal with North Castle Partners. Meanwhile, Earth Treks Climbing and Fitness signed with Tengram Capital Partners for undisclosed amount before merging with Planet Granite, becoming largest climbing gym company in United States, ultimately transforming into El Cap Holdings).]

279. For further discussion of the importance of routesetting for indoor rock climbing businesses, see supra notes 45, 71-79 and accompanying text.

280. See Jason Pill, Ask A Lawyer: Are All Climbing Gyms At Risk Of Being Shut Down?, Climbing Business Journal (Oct. 25, 2019), https://www.climbingbusiness journal.com/ask-a-lawyer-are-all-climbing-gyms-at-risk-of-being-shut-down/\#: : text $=$ for $\% 20$ the $\% 20$ majority $\% 20$ of $\% 20$ climbing,agreement $\% 20$ or $\% 20$ commercial \%20loan\%20documents [https://perma.cc/CS39-FUKZ] (emphasizing importance of insurance policies, safety protocols, liability waivers to reduce risk of litiga- 
Tamerler: Indoor Rock Climbing: The Nuts and Bolts of Routesetting Copyrigh

must learn how to respect the intellectual property of other setters to ensure that they follow the law and avoid conflict. ${ }^{281}$ While the issue of indoor rock climbing routes and copyright has not been fully explored, it is bound to become a significant legal issue for those in the industry. ${ }^{282}$

tion; further, emphasizing how indoor rock climbing gyms need to examine law to prepare for potential issues).

281. See id. (discussing importance of indoor rock climbing industry keeping abreast of legal issues).

282. See supra note 2 (discussing current legal landscape surrounding indoor rock climbing, emphasizing importance of keeping up to date regarding potential liabilities). 
Jeffrey S. Moorad Sports Law Journal, Vol. 28, Iss. 1 [], Art. 1 